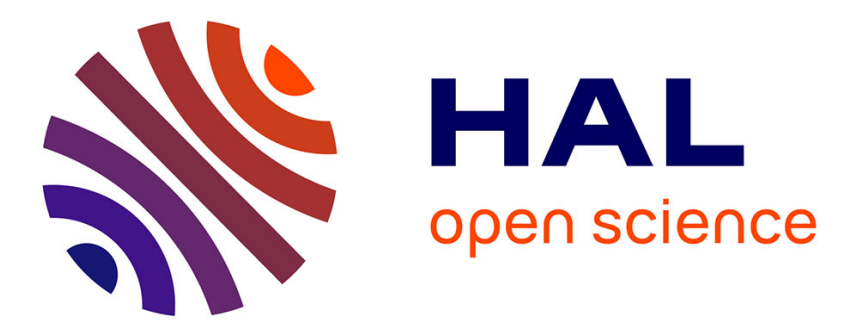

\title{
Somatostatin interneurons delineate the inner part of the external plexiform layer in the mouse main olfactory bulb
}

Gabriel Lepousez, Zsolt Csaba, Véronique Bernard, Catherine Loudes, Catherine Videau, Joelle Lacombe, Jacques Epelbaum, Cécile Viollet

\section{To cite this version:}

Gabriel Lepousez, Zsolt Csaba, Véronique Bernard, Catherine Loudes, Catherine Videau, et al.. Somatostatin interneurons delineate the inner part of the external plexiform layer in the mouse main olfactory bulb. Journal of Comparative Neurology, 2010, 518 (11), pp.1976-1994. 10.1002/cne.22317 . hal-03013523

\section{HAL Id: hal-03013523 \\ https://hal.science/hal-03013523}

Submitted on 19 Nov 2020

HAL is a multi-disciplinary open access archive for the deposit and dissemination of scientific research documents, whether they are published or not. The documents may come from teaching and research institutions in France or abroad, or from public or private research centers.
L'archive ouverte pluridisciplinaire HAL, est destinée au dépôt et à la diffusion de documents scientifiques de niveau recherche, publiés ou non, émanant des établissements d'enseignement et de recherche français ou étrangers, des laboratoires publics ou privés. 
Somatostatin interneurons delineate the inner part of the External Plexiform Layer in the mouse main olfactory bulb

\begin{tabular}{|r|l|}
\hline Journal: & The Journal of Comparative Neurology \\
\hline Manuscript ID: & JCN-09-0075.R3 \\
\hline Wiley - Manuscript type: & Research Article \\
\hline Keywords: & SRIF, neuropeptide, GABA, Van Gehuchten, EPL, reciprocal synapse \\
\hline \multicolumn{2}{|}{} \\
\hline
\end{tabular}

\section{S) ScholaroNE \\ Manuscript Central}


Somatostatin Interneurons Delineate the Inner Part of the External Plexiform Layer in the Mouse Main Olfactory Bulb.

Gabriel Lepousez $^{1,2}$, Zsolt Csaba ${ }^{3,4}$, Véronique Bernard ${ }^{2,5}$, Catherine Loudes ${ }^{1,2}$, Catherine Videau $^{1,2}$, Joelle Lacombe ${ }^{6}$, Jacques Epelbaum $^{1,2}$, Cécile Viollet $^{1,2} *$

\section{Affiliations:}

1: Inserm UMR 894, Center for Psychiatry and Neurosciences, F-75014 Paris, France.

2: Université Paris-Descartes-Faculté de Médecine, F-75006 Paris, France.

3: Inserm UMR 676, F-75019 Paris, France.

4: Université Denis Diderot-Paris 7, F-75005, Paris, France.

5: Inserm UMR 686, F-75006 Paris, France.

6: Service de Neuropathologie, Centre Hospitalier Sainte-Anne, F-75014 Paris, France.

Abbreviated title: Somatostatin in the mouse main olfactory bulb

Associate Editor: Paul E. Sawchenko

Keywords : SRIF, neuropeptide, GABA, Van Gehuchten, EPL, reciprocal synapse.

* Corresponding author at: Inserm UMR 894, Centre de Psychiatrie et Neurosciences, $2^{\text {ter }}$ rue d'Alésia, F-75014 Paris, France.

Tel: +331407892 32, fax: +33145807293.

E-mail address: cecile.viollet@inserm.fr (C. Viollet).

\section{Support and grant information: ${ }^{1}$}

\footnotetext{
${ }^{1}$ This study was supported by Inserm and MENRT (fellowship to G.L.).
} 


\begin{abstract}
Neuropeptides play a major role in the modulation of information processing in neural networks. Somatostatin, one of the most concentrated neuropeptides in the brain, is found in many sensory systems including the olfactory pathway. However its cellular distribution in the mouse main olfactory bulb (MOB) is yet to be characterized. Here we show that $\sim 95 \%$ of mouse bulbar somatostatin-immunoreactive (SRIF-ir) cells describe a homogeneous population of interneurons. These are restricted to the inner lamina of the external plexiform layer (iEPL) with dendritic field strictly confined to the region. iEPL SRIF-ir neurons share some morphological features of Van Gehuchten short-axon cells, and always express glutamic acid decarboxylase, calretinin and vasoactive intestinal peptide. One half of SRIF-ir neurons are parvalbumin-ir revealing an atypical neurochemical profile when compared to SRIF-ir interneurons of other forebrain regions such as cortex or hippocampus. Somatostatin is also present in fibers and in a few sparse presumptive deep short-axon cells in the granule cell layer (GCL) which were previously reported in other mammalian species. The spatial distribution of somatostatin interneurons in the MOB iEPL clearly outlines the region where lateral dendrites of mitral cells interact with GCL inhibitory interneurons through dendrodendritic reciprocal synapses. Symmetrical and asymmetrical synaptic contacts occur between SRIF-ir dendrites and mitral cell dendrites. Such restricted localization of somatostatin interneurons and connectivity in the bulbar synaptic network strongly suggest that the peptide plays a functional role in the modulation of olfactory processing.
\end{abstract}




\section{Introduction}

The olfactory bulb (OB), the first central relay in olfactory processing, is a good model for deciphering the function of interneurons. Within its well-defined cytoarchitectural organisation, numerous interneurons contribute to the processing of sensory information, through direct or indirect innervation of olfactory inputs and mitral/tufted cells (Shepherd, 2004; Shipley and Ennis, 1996). Periglomerular and granule cells, interneurons which populate the glomerular (GL) and granule cell (GCL) layers respectively, have been extensively studied (Shepherd, 2004). Directly innervating the principal cells, these cells are classically considered first order neurons. Remaining interneurons are classified as second order interneurons, since they only interact with first order neurons (Schneider and Macrides, 1978).

Morphological analysis of interneurons, combined with descriptions of their neurochemical content for calcium-binding proteins or neuropeptides, has allowed for a better understanding of their diversity, notably in the telencephalon (for a review, see Ascoli et al., 2008; Klausberger et al., 2003; Markram et al., 2004). Among neuropeptides, somatostatin (SRIF) is extensively expressed in a large subset of GABAergic interneurons throughout the telencephalon which specifically innervate principal cells in most brain regions (reviewed in Viollet et al., 2008). Through the activation of five specific G protein-coupled receptors, sst1 to 5 , somatostatin is involved in various central functions from classical neuroendocrine control to cognitive functions. In the olfactory bulb, SRIF-ir interneurons have been described in several mammalian species (Davis et al., 1982; Gutièrrez-Mecinas et al., 2005; Matsutani et al., 1989; Ohm et al., 1988; Scott et al., 1987; Seroogy et al., 1989). In these species, SRIF is systematically found in deep short-axon cells of the GCL. It has also been reported in few rare EPL interneurons in guinea pigs, periglomerular cells in rats and, to a lesser extent, periglomerular cells in humans. Surprisingly the presence of SRIF-ir interneurons in the mouse olfactory bulb had not yet been described. Since mice are becoming increasingly important as models of nervous system function and since neuroanatomical divergence between mouse and rat olfactory bulb exists (Kosaka and Kosaka, 2007a, Kosaka and Kosaka 2007b), we undertook to map the somatostatinergic system in the mouse main olfactory bulb (MOB) using light microscopic immunohistochemical and ultrastructural studies. The results indicate that SRIF interneurons in the iEPL are in a key position to modulate the bulbar synaptic network. 


\section{Materials and Methods}

\section{Animals}

Two-three month-old male wild-type ( $n=23)$ and homozygous SRIF knockout $(\mathrm{KO}, \mathrm{n}=3)$ littermates were obtained from a somatostatin knockout strain (Zeyda et al., 2001) backcrossed onto a $\mathrm{C} 57 \mathrm{Bl} / 6 \mathrm{~J}$ genetic background for thirteen generations. Swiss $(\mathrm{n}=3)$ and FVB/V $(n=3)$ mice were obtained from Charles Rivers (L'Arbresles, France). Animals were housed and bred in our Research Center animal facilities under a 12h/12h light/dark cycle. All animal procedures complied with French laws regarding animal experimentation (Decree n॰87-848, 19 October 1987 and the Ministerial Decree of 19 April 1988) and recommendations of a local ethical committee.

\section{Antibodies characterization}

The main characteristics of the primary and secondary antibodies used in the present study are summarized in Table 1.

The calbindin D-28k (CB) antibody \#300 specifically stains the ${ }^{45}$ Ca-binding site of calbindin D-28K(MW $28 \mathrm{kDa}$, IEP 4.8) in a two-dimension immunoblot of rabbit cerebellum extract. Using radioimmunoassay, it detects calbindin D-28k in rat brain tissue with a sensitivity of $10 \mathrm{ng} /$ assay and an affinity of $1.6 \times 10^{-12} \mathrm{M} / \mathrm{L}$ (Celio et al., 1990). In mouse olfactory bulb, the predominant labeling of the glomerular layer described herein was also reported using other mouse (Kosaka et al., 2005) and rabbit (Parrish-Aungst et al., 2007) calbindin antibodies.

The calretinin (CR) antibody \#AB1550 recognizes a $31 \mathrm{kD}$ band in western blot and a spot corresponding to the expected size and isoelectric point for calretinin in a two-dimension immunoblot of rat cerebellum (Winsky et al., 1996). The immunohistochemical pattern obtained in rat brain sections is consistent with the one obtained with a well characterized rabbit antiserum and it disappears after preabsorption with purified rat recombinant calretinin (Winsky et al., 1996). As previously reported in another study in mouse (Parrish-Aungst et al., 2007), the labeling pattern observed in our study is similar to those observed with other goat (Kosaka and Kosaka, 2007a), mouse (Batista-Brito et al., 2008; Kosaka and Kosaka, 2007a), and rabbit 
(Kosaka and Kosaka, 2007a; Kosaka et al., 2005) calretinin specific antibodies in the murine MOB.

The parvalbumin (PV) antibody \#AB9314 detects a single $12 \mathrm{kDa}$ band in immuno blots of soluble proteins from rat and mouse whole brain and precipitates a single PV band from whole brain homogenates. Specificity tests revealed no cross-reactivity with calmodulin, calbindin-D28k or calretinin (Pr. Ken Baimbridge, Univ. of British Columbia, Vancouver, Canada, personal communication). In the present study, it labels the EPL and IPL/superficial GCL layers, as also observed using other mouse (Parrish-Aungst et al., 2007) and rabbit (Kosaka and Kosaka, 2008) parvalbumin antibodies.

The Tyrosine Hydroxylase (TH) antiserum \#AB152 recognizes a single band around 62 $\mathrm{kDa}$ in immunoblotted brain tissues, consistent with the size of the Tyrosine Hydroxylase protein (Manufacturer's technical information). Herein, it strongly labels the glomerular layer in the mouse MOB, as previously observed, using other rabbit (Batista-Brito et al., 2008; Kosaka et al., 2005; Kosaka and Kosaka, 2008; Parrish-Aungst et al., 2007), mouse (Panzanelli et al., 2007) or sheep (Kosaka and Kosaka, 2007b) Tyrosine Hydroxylase antibodies. This staining pattern is also consistent with the transgene expression patterns obtained either in Tyrosine Hydroxylase-lacZ or Tyrosine Hydroxylase-GFP mice (Saino-Saito et al., 2004). Furthermore, in an experimental model for olfactory deprivation (Viollet et al., unpublished data), Tyrosine Hydroxylase staining strongly decreased as previously reported in olfactory deprivation studies (Baker et al., 1993).

The goat somatostatin antibody \#D-20 labels a $17 \mathrm{kD}$ human recombinant somatostatin transfected protein by western blotting (Manufacturer's technical information). The sequence of the immunizing peptide used to raise this antibody is unavailable in the manufacturer's information. The sequence given in Table 1 was obtained by mass spectrometry analysis of the blocking peptide (sc-7819 P; Santa Cruz Biotechnology, Santa Cruz, CA) (Cox et al., 2008). The staining pattern obtained with this antibody in rat MOB is identical to (data not shown) the one previously reported with another rabbit SRIF antiserum (Hwang et al., 2004) and SRIF immunoreactivity was totally absent in brain sections processed from SRIF KO mice (Supplemental figure S1).

The specificity of the rabbit somatostatin polyclonal antiserum IS-7 (Ciofi et al., 2006) was tested by preabsorption with increasing concentrations of SRIF28[1-12], SRIF28[1-14] or SRIF28, and all three peptides abolished staining (P. Ciofi, personal communication). The 
immunoreactive signal is totally absent in brain sections from somatostatin $\mathrm{KO}$ mice (data not shown).

The glutamic acid decarboxylase (GAD) 65/67 antibody \#G1563 specifically recognizes a doublet of bands at 65-67 kDa when immunoblotting rat brain extracts. The staining disappears in the presence of GAD65/67 peptide (human, amino acids 579-594 with N-terminally added lysine) (Manufacturer's technical information). An identical staining pattern was reported in the mouse MOB using this antibody (Kosaka and Kosaka, 2007a; Kosaka et al., 2005; Kosaka and Kosaka, 2007b).

The glial fibrillary acidic protein antibody \#Z0334 recognizes the native (49 $\mathrm{kDa})$ and proteolytic (40-47 kDa) bands on a western blot of adult mouse brain (García-Sevilla et al., 2004). The reported distribution of GFAP in mouse olfactory bulb (Monnier et al., 1999) is identical to the one described herein.

The specificity controls performed by ICC and RIA of the cholecystokinin (CCK) antiserum IS-15/8 show expected cross-reaction with gastrin (Ciofi and Tramu, 1990). CCK labeling is mainly found in large somata at the EPL/GL border (presumably in medium-sized tufted cells), as also reported using a mouse monoclonal antibody (Kosaka et al., 2005; Kosaka and Kosaka, 2007b).

Labeling with the neuropeptide Y (NPY) antiserum IS-12 is abolished after preabsorption with increasing concentrations of NPY peptide (Ciofi et al., 1991). Furthermore, the staining is the same with an antibody against the C-terminal part of the NPY precursor (C-PON, Ciofi et al., 1991).

The staining specificity of the vasoactive intestinal peptide (VIP) antiserum IS-21 was previously described (Maubert et al., 1990). VIP antiserum was preadsorbed with homologous (VIP) or heterologous antigens (NPY and C-PON) at various concentrations. Abolition of the VIP staining was observed only with the homologous antigen. The absence of cross-reactivity of the antiserum for several non-related peptides (substance P, SRIF $1-28$, arginine-vasopressin, oxytocin and angiotensin II) was also demonstrated by radioimmunoassay.

The Post-Synaptic Density 95K protein (PSD-95) antibody \#MA1-046 detects a 95 kDa protein in rat brain extracts (Kornau et al., 1995 and Manufacturer's instructions). Using this antibody, staining in the OB is the same as the one observed with the \#05-494 mouse antibody (Upstate Biotech., Lake Placid, NY, USA) whose specificity was confirmed by the extinction of 
the $95 \mathrm{kDa}$ signal detected by immunoblotting in brain extracts when using PSD-95 KO mice (Rasband et al., 2002).

In rat CNS, the staining pattern obtained with the guinea-pig vesicular GABA transporter (VGAT) antibody \#AB5855 is in agreement with the pattern described using other VGAT antisera (Belenky et al., 2008). This staining is abolished by preadsorption with the immunogen peptide (Manufacturer's instructions). In a recent study in mouse MOB, another rabbit VGAT antiserum (\#131002, Synaptic Systems, Göttingen, Germany) and the antibody \#AB5855 displayed an identical staining pattern in doubleimmunofluorescence experiments (Panzanelli et al., 2007). Antibody \#131002 recognizes a doublet of bands migrating at the expected size for VGAT in brain tissue and heterologous expression systems (Takamori et al., 2000).

\section{Tissue preparation for light and fluorescent microscopy}

Mice were deeply anesthetized following intraperitoneal injection of sodium pentobarbital (180 mg/kg, Ceva Sante Animal, Libourne, France) and transcardially perfused with $0.9 \% \mathrm{NaCl}$ then $4 \%$ paraformaldehyde (PFA) in $0.1 \mathrm{M}$ phosphate buffer $\mathrm{pH}=7.4$ (PB). Brains were quickly removed, post-fixed overnight in 4\% PFA, incubated in 30\% sucrose in phosphate buffered saline (PBS) for 24 hours, then quickly frozen with ice-cold isopentane and stored at $-80^{\circ} \mathrm{C}$. MOB coronal sections were prepared using a freezing microtome (CM 1325, Leica, Heidelberg, Germany).

MOB somatostatin interneurons distribution and morphological analysis.

Chromogenic somatostatin immunohistochemistry was performed using the standard ABCDAB method on $40 \mu \mathrm{m}$-thick floating serial sections (inter-slice interval: $120 \mu \mathrm{m}$ ). After incubation with $1 \% \mathrm{H}_{2} \mathrm{O}_{2}$ in PBS, sections were incubated for one hour with $5 \%$ normal donkey serum (NDS, Biowest, Nuaillé, France) and 5\% bovine serum albumin (BSA, Sigma, St Louis, MO, USA) in PBS containing 0.3\% Triton X-100 (PBST). They were then incubated with goat anti-somatostatin antibody in $\mathrm{PBST} / 1 \% \mathrm{NDS} / 1 \% \mathrm{BSA}$ for six days at $4{ }^{\circ} \mathrm{C}$, rinsed with $\mathrm{PBS}$, then incubated with biotinylated anti-goat secondary antibody in PBST/1\% NDS/1\% BSA for 90 
minutes at room temperature (RT) (Table 1). After rinses, ABC Elite reagent (Vector laboratories, Burlingame, CA, USA) was applied to the sections and revelation was performed with 3-3'-diaminobenzidine (DAB, Sigma; $0.5 \mathrm{mg} / \mathrm{ml}$ in $\mathrm{PBS} / 0.02 \% \mathrm{H}_{2} \mathrm{O}_{2}$ ) for one minute. Sections were then counterstained with cresyl violet, and mounted for light microscopic observation. Immunohistochemical specificity controls for somatostatin labeling consisted of incubation in absence of the primary anti-somatostatin antibody.

The analysis of somatostatin-ir cell relative distribution in the olfactory bulb was performed on three mice (12 sections each, mean number of analyzed SRIF-ir cells per animal: 1195.9 \pm 20.4 ). Given the relatively low density of SRIF-ir cells in the olfactory bulb, all SRIF-ir somata were counted in each layer of the DAB-processed MOB sections (section thickness, 40 $\mu \mathrm{m})$ under a 40x objective using a Lumenera Infinity 2 CCD color camera (Lumenera, Ottawa, Canada) linked to the image analysis mapping software (Mercator, Explora Nova, La Rochelle, France).

For camera lucida analysis SRIF-ir cells were randomly sampled from the DAB-processed sections ( $n=53$ cells for $\mathrm{iEPL} ; \mathrm{n}=30$ cells for GCL, from three animals) and observed under an Olympus BH2 light microscope (Olympus, Tokyo, Japan). The projected contours of SRIF-ir neurons showing well stained processes were traced using a camera lucida with 40x or 20x immersion planapochromatic objectives (Olympus, Tokyo, Japan) for iEPL and GCL cells respectively (magnification 500x and 250x). Drawings were scanned with a flat bed scanner (resolution: $300 \mathrm{dpi}$ ) and transfered to a personal computer. Measurement of the area, area equivalent diameter, perimeter, minor and major diameters of the soma, number of primary dendrites (exit points from the soma) and dendritic branching points were performed from each individual immunoreactive neuron using NIH ImageJ 1.33 (NIH, Bethesda, MD, USA). Sholl crossing analysis was performed using a transparent mask displaying concentric circles (intercircle interval: $10 \mu \mathrm{m}$ ) centered on each individual soma. The furthest dendrite intercept (ie the radius of the largest virtual sphere centered on the soma, still intercepted by the dendrite) was expressed as a mean \pm standard error of the mean (SEM).

Illustrations correspond to the projected contours of DAB stained somata of representative SRIF-ir neurons, camera lucida drawn using a 100x oil immersion objective lens (magnification 1250) and scanned with a flat bed scanner (resolution: 300 dpi). Images were adjusted for levels using Photoshop (CS2, Adobe Systems, San Jose, CA, USA). No correction for tissue shrinkage 
was performed in the analysis of $\mathrm{ABC}-\mathrm{DAB}$ sections.

\section{Immunofluorescence double-labeling and cell counts.}

For simultaneous detection of somatostatin with other markers (see Table 1) fluorescent immunohistochemistry was performed using standard methods on $30 \mu \mathrm{m}$-thick serial sections. After blocking with 5\% NDS/5\% BSA in PBST, sections were incubated for 48 hours at $4{ }^{\circ} \mathrm{C}$ in $\mathrm{PBST} / 1 \% \mathrm{NDS} / 1 \% \mathrm{BSA}$ with mixtures of primary antibodies raised in distinct species for somatostatin and each marker (see details and final concentrations in Table 1). After rinsing, a mixture of appropriate fluorescence-conjugated secondary antibodies in the same buffer (Table 1) was applied for 90 minutes at room temperature. Sections were mounted with Fluoromount mounting medium (Southern Biotech, Birmingham, AL, USA). In the case of GAD 65/67 immunohistochemistry, cryostat-cut $16 \mu \mathrm{m}$-thick MOB sections (2800 Frigocut E, Reichert-Jung, Leica, Hedelberg, Germany) were processed as described above, except that incubation with both primary antibodies lasted one week and that detergent was omitted in all steps. Fluorescence signals were detected using an epifluorescence microscope (Axioplan 2, Carl Zeiss, Jena, Germany) fitted with standard filters for the visualization of A488 and CY3 fluorochroms. The relative distribution of SRIF-ir cells in the MOB did not statistically differ between fluorescenceprocessed and DAB-processed SRIF immunohistochemistry experiments (data not shown).

Immunohistochemical specificity controls for somatostatin labeling were previously mentioned. In the case of multiple labeling, specificity controls included omission of the primary antibodies to evaluate the non-specific binding of the secondary antibodies as well as incubation with one primary but both secondary antibodies to demonstrate the absence of cross labeling.

To assess the neurochemical nature of the iEPL and GCL somatostatinergic cells, SRIF-ir cells were analyzed for coexpression with different interneuronal markers (see Table 3). The total number of cells immunoreactive for each marker (Marker-ir population) or somatostatin (SRIF-ir population) was counted in both layers and all SRIFir cells were individually checked for presence (SRIF/marker) or absence (SRIF alone) of coexpression. All data were averaged from counts derived from three mice, with six sections being analyzed in each animal (section thickness $30 \mu \mathrm{m}$, inter-slice interval: $180 \mu \mathrm{m}$ ). Numbers of analyzed cells per animal and colocalization percentages (averaged from the colocalization 
percentages per animal, $n=3$ ) are given in Table 3 as mean percentage \pm SEM. The proportion of cells expressing the marker also positive for SRIF is expressed as « percent colocalization in Marker population " whereas the proportion of SRIF-ir cells coexpressing a marker is expressed as « percent colocalization in SRIF population».

For each marker, colocalization with SRIF immunoreactivity was confirmed by confocal microscopy on a representative sample of cells $(n=25)$. Single laser beams (wavelengths 488 and $543 \mathrm{~nm}$ ) were alternately used using a TCS SP2 confocal imaging system equipped with Ar 488$\mathrm{nm}$ and HeNe 543-nm lasers (Leica Microsystem, Heidelberg, Germany). For each optical section, double-fluorescence images were acquired under a 40x oil-immersion objective (numeric aperture 1.25) in sequential mode to avoid potential contamination by linkage specific fluorescence emission cross-talk to collect images for both fluorescent signals. These analyses allowed 1) to confirm the correct penetration of both antibodies through the whole section and 2) to validate somatostatin/marker colocalization in a three-dimensional space. Confocal analysis was also used to assess the colocalization of NPY with somatostatin in GCL fibers. Panels displayed in Fig. 3 correspond to five (A,E) or ten (B,C,D,F) serial optical slices spaced by 200$400 \mathrm{~nm}$ stacked along the z-axis with maximum intensity projection mode. Once acquired, confocal pictures were exported into Photoshop software (CS2, Adobe Systems, San Jose, CA, USA) and adjusted for levels, luminosity and contrast. Final composites were assembled using Illustrator software (CS2, Adobe Systems).

\section{Electron microscopy.}

Pre-embedding immunocytochemical procedures were performed for SRIF detection at the ultrastructural level. Mice were fixed using gravity-driven transcardially perfusion with $10 \mathrm{ml}$ of $0.9 \% \mathrm{NaCl}$, followed by $50 \mathrm{ml}$ of $\mathrm{PB} / 4 \% \mathrm{PFA} / 0.05 \%$ glutaraldehyde (Sigma) except for panel E which corresponds to $\mathrm{PB} / 2 \% \mathrm{PFA} / 0.5 \%$ glutaraldehyde perfusion conditions. Brains were postfixed overnight in $4 \% \mathrm{PFA}$ at $4^{\circ} \mathrm{C}$. Seventy $\mu \mathrm{m}$ coronal sections were cut using a vibratome (VT1000S, Leica, Heidelberg, Germany) and collected in 0.01 M PBS, pH 7.4. Sections were equilibrated in $30 \%$ sucrose and $10 \%$ glycerol in PB, subjected to three freeze/thaw cycles using cold isopentane and rinsed in PBS. Sections were incubated sequentially in $1 \%$ sodium borohydride $(\mathrm{NaBH} 4)$ in PBS for 5 minutes, rinsed with PBS, and processed for 
somatostatin chromogenic immunohistochemistry (see above) except that primary antibody incubation was overnight and DAB revelation lasted 3-10 min. Sections were post-fixed first in $1 \%$ glutaraldehyde, then in $1 \%$ osmium tetroxide in $\mathrm{PB}$ for 10 minutes at room temperature. After PB rinses, sections were dehydrated in ascending series of ethanol concentrations, which included $1 \%$ uranyl acetate in $70 \%$ ethanol. They were then treated twice with propylene oxide for 10 minutes, equilibrated overnight in Durcupan ACM (Fluka, Sigma), mounted on glass slides and cured at $60^{\circ} \mathrm{C}$ for $48 \mathrm{~h}$. Areas of interest were cut out from the slide and glued to blank cylinders of resin. Immunoreactive samples were carefully identified on thick sections and cut in semithin sections $(500 \mathrm{~nm})$ and then in ultrathin sections $(45 \mathrm{~nm})$ with an ultramicrotome (Ultracut S, Reichert, Leica, Heidelberg, Germany). Consecutive ultrathin sections were collected on 200-mesh copper grids (AGAR Scientific, U.K.) and stained with lead citrate before examination with a Philips CM100 electron microscope (Philips, Suresnes, France). Once acquired, all images presented herein were exported and adjusted for levels, luminosity and contrast with Photoshop software (CS2, Adobe Systems, San Jose, CA, USA). Final composites were assembled using Illustrator software (CS2, Adobe Systems).

\section{Triple-labeling of somatostatin dendrites with synaptic markers.}

To combine multiple labeling of somatostatin with glutamatergic and GABAergic synaptic markers, immunofluorescence was performed according to Schneider-Gasser et al., (2006). Briefly, mice were anesthetized with pentobarbital (180 mg/kg) and transcardially perfused with a $4^{\circ} \mathrm{C}$ normal artificial cerebrospinal fluid solution containing (in $\mathrm{mM}$ ): $124 \mathrm{NaCl}$, $3 \mathrm{KCl}, 2 \mathrm{CaCl} 2,1.3 \mathrm{MgSO}_{4}, 25 \mathrm{NaHCO}_{3}, 1.2 \mathrm{NaH}_{2} \mathrm{PO}_{4}$, and 10 D-glucose, $\mathrm{pH}$ 7.3. The brain was rapidly removed and $200 \mu \mathrm{m}$-thick horizontal slices were immediately cut with a vibrating microslider (World Precision Instruments, Sarasota, FL, USA). Slices were immediately transferred to cold 4\% PFA for 30 min, rinsed twice in PBS and incubated in $\mathrm{PBS} / 30 \%$ sucrose overnight. Tissue-Tek- (Sakura Finetek France, Villeneuve d'Ascq, France) embedded slices were then cut using a cryostat into $14 \mu \mathrm{m}$-thick sections and mounted onto glass Superfrost Plus slides. Multiple immunohistochemical labeling was performed as mentioned above, using a combination of goat SRIF, mouse PSD-95 and guinea-pig vesicular GABA transporter antibodies, followed by coincubation with the appropriate fluorescent secondary antibodies (see Table 1 for antibodies details). After mounting, sections were submitted to confocal observation 
(SP2, Leica, Heidelberg, Germany) under a 63x objective (numeric aperture: 1.4) to select representative well delineated somatostatin dendrites. Series of 10-15 confocal sections spaced by $300-500 \mathrm{~nm}$ were acquired using sequential acquisition of separate wavelength channels (laser wavelengths : 488, 543 and $633 \mathrm{~nm}$ ). The signal was treated with line averaging to integrate the signal collected over four frames to reduce noise. When necessary, background noise was reduced using "smooth edge" image filter (Leica Confocal Software LCS, Leica, Heidelberg, Germany).

The colocalization pattern of total and somatostatin-ir dendrite-associated VGAT and PSD-95 immunoreactive clusters was determined from 50 confocal sections (resolution: 60 $\mathrm{nm} /$ pixel) using Imaris software (Bitplane, Zurich, Switzerland). For each section, each singlelabeled VGAT or PSD-95 immunoreactive cluster was identified by a segmentation algorithm (intensity threshold: $15-25 \%$ of the highest intensity value, surface threshold: $0.05 \mu \mathrm{m}^{2}$ ) and their number and size were calculated. A colocalization algorithm was then used to identify the proportions of VGAT/PSD-95 colocalized clusters as well as the proportion of surface shared by the two markers. In the case of dendrite-associated somatostatin labeling, which did not correspond to the entire surface of dendrites, we considered the clusters as being included in SRIF-ir dendrite using a conservative estimate corresponding to a surface threshold of $0.1 \mu \mathrm{m}^{2}$, ie $25 \%$ of mean PSD-95 surface.

\section{Statistical Analysis}

Neuroanatomical and neurochemical data were analyzed using Statview 5.0 software (SAS, Cary, NC, USA). Somatic parameters of iEPL and GCL types of neurons were compared using ANOVA and SRIF-ir cell densities were compared between the different layers using repeated-measures ANOVA. Results are expressed as mean \pm SEM. Distribution normality of each subgroup of SRIF-ir neurons was tested for the soma equivalent diameter using the ShapiroWilk test with StatEL software (Ad Science, Paris, France). Neurochemical data expressed as proportions were tested using a t-test. Chi-square analysis was used to compare the distribution of VGAT and PSD95 clusters in the total population vs in SRIF-ir dendrites. 


\section{Results}

\section{Somatostatin-ir in the mouse MOB}

As shown in Fig. 1A, the somatostatin-ir pattern is layer-specific. Somata and processes are mainly found in the inner sublayer of the EPL $(88.5 \pm 0.6 \%$ of total SRIF-ir cells, Fig. 1, panels A and C1-C3). Both adjacent layers of the iEPL, the mitral cell layer (MCL) and the outer sublayer of the EPL (oEPL), display low immunoreactivity $(2.8 \pm 0.3 \%$ and $3.4 \pm 0.5 \%$ respectively) with some rare somata sending their processes into the iEPL (see arrowheads, Fig. 1A). Somatostatin-ir labeling of the MCL and EPL layers delimits a unique ribbon-like staining pattern in the MOB accounting for $94.7 \%$ of total SRIF cells. Somatostatin staining is also found in the granule cell layer (GCL), in a few strongly labeled large cells (3.1 $\pm 0.3 \%$; Fig. 1, panels A and B1-B3) as well as in a high density of fibers that spread throughout the GCL and along the inner plexiform layer (IPL). In the glomerular layer (GL) a few processes and faintly stained somata $(2.1 \pm 0.1 \%$, open arrow, Fig. 1A) are observed. Finally, no significant cellular staining is visible in the IPL $(<0.1 \%)$. Most immunoreactive cellular profiles display morphological characteristics of interneurons (Fig. 1, panels B1-B3, C1-C3) and not large-bodied mitral/tufted cells or asymmetric star-like glial figures. Olfactory axons are not stained. Such an immunoreactivity pattern, observed in the $\mathrm{C} 57 \mathrm{Bl} / 6 \mathrm{~J}$ olfactory bulb, was also found in two other murine strains commonly used, the Swiss and FVB/V strains. This pattern is totally absent in SRIF KO mice (Suppl. Fig. S1).

\section{Morphological analysis of SRIF-ir cells in the mouse iEPL and GCL}

Morphometric analyses of camera lucida drawings reveal that iEPL SRIF-ir cells (Fig. 2, top part) constitute a homogeneous population whose main cellular attributes are summarized in Table 2. These cells show small round to piriform somata, localized in a regular manner along the inner part of the EPL. Their soma area equivalent diameter fits to a normal distribution ( $\mathrm{n}=53$, Shapiro-Wilk test, $\mathrm{W}=0.99, \mathrm{p}=0.8$ ). A few thick primary processes emerge from the soma. They have numerous large varicosities and rarely bear spines. Their dendritic field is relatively small with few branching processes that elaborate in close proximity to the cell body (mean furthest 
dendrite Sholl intercept : $77.0 \pm 2.6 \mu \mathrm{m}, \mathrm{n}=53$ ) and remain restricted to the $\mathrm{iEPL}$ (Fig. $1 A, 2$ top part). Somatostatin-ir axon-like structures were not detected. Altogether, these morphological characteristics correspond to those reported for Van Gehuchten cells (see below in Discussion).

The few inframitral SRIF-ir neurons mostly found scattered in the deep part of the murine GCL are large and multipolar (Fig.1 A, B1-3). Their somata are ovoid to fusiform, displaying homogeneous characteristics as detailed in Table 2. The area equivalent diameter of the soma also fits to a normal distribution $(n=30$, Shapiro-Wilk test, $W=0.98, p=0.8)$. Two to seven primary processes develop into poorly ramified lengthy neurites (Fig. 2, bottom part) oriented in parallel to GCL striations and projecting into the IPL, running up to $400 \mu \mathrm{m}$ from the soma (mean furthest dendrite Sholl intercept, 209.3 $\pm 16.1 \mu \mathrm{m}, \mathrm{n}=30$, Fig. 2, bottom part). These processes are not spiny but show a few small varicosities. GCL SRIF-ir neurons thus share some morphological properties with deep short-axon cells (see below in Discussion).

In addition to identified cellular processes, SRIF-ir fibers that are not connected to visible perikarya are observed in the GCL. They also progress in parallel to the striations of the GCL and IPL, bear few small varicosities and branch very rarely.

\section{Neurochemical characterization of SRIF-ir interneurons in the mouse MOB}

The neurochemical properties of iEPL and GCL SRIF-ir cell populations were characterized using fluorescent double immunostaining procedures. We analyzed the extent of colabeling between somatostatin and markers of bulbar interneurons or SRIF interneurons in other telencephalic regions (see Table 1 for experimental details, Table 3 for results).

In the iEPL, immunostaining for GAD65/67 reveals a dense fiber mesh corresponding mainly to GCL granule cell dendritic projections to the EPL, with small to medium-sized GABAergic somata. All SRIF-ir somata are also GAD65/67-ir (Fig. 3A, Table 3), accounting for $13.9 \%$ of the iEPL GABAergic population. Concerning calcium-binding proteins commonly used as markers for GABAergic neurons, calretinin is found in small to medium-sized neurons all over the iEPL. All SRIF-ir interneurons are calretinin-ir (Fig. 3B, Table 3), constituting a third of the total calretinin population of the iEPL. Parvalbumin is also found in the iEPL in small to medium-sized neurons scattered in the layer. Only half of iEPL SRIF-ir neurons (51.1\%) coexpress parvalbumin. These double- 
labeled cells correspond to $59.1 \%$ of the iEPL parvalbumin population (Fig. 3C, Table 3). Finally immunoreactivity for calbindin in the iEPL is found in rare medium-sized neurons which are immunonegative for somatostatin (Table 3).

SRIF-ir neurons were further characterized by analyzing their colocalization with typical interneuronal markers. In the iEPL, vasoactive intestinal peptide is predominantly found in small to medium-sized neurons. Nearly all SRIF-ir interneurons are also VIP-ir and they account for $37.5 \%$ of the VIP-ir population of the iEPL (Fig. 3D, Table 3). On the other hand, SRIF-ir interneurons do not express neuropeptide $Y$ which is barely present in the iEPL. Cholecystokinin is mostly expressed in large somata in the iEPL and never colocalized with SRIF immunoreactivity. Similarly the dopaminergic marker tyrosine hydroxylase which labels small to medium-sized iEPL neurons (Table 3) is not expressed in SRIF-ir neurons. Finally, SRIF staining was never found associated with glial fibrillary acidic protein immunoreactivity which occurs in star-like immunoprofiles in the iEPL (data not shown).

In the GCL, GAD65/67 cellular staining corresponds to packed intrinsic populations of GABAergic interneurons, including granule cells (Fig. 3E). The few SRIF-ir deep shortaxon cells are all labeled by the GAD65/67 antibody (Table 3). Concerning calcium-binding proteins, a high level of CR immunoreactivity is found in the GCL, especially in a population of superficial granule cells as well as in sparse superficial large multipolar cells. This pattern does not overlap with the SRIF-ir pattern (Table 3). Parvalbumin immunoreactivity is mostly found in large multipolar neurons restricted to the superficial part of the GCL and only $1.7 \%$ of SRIF-ir cells demonstrate PV coexpression (Table 3). Calbindin immunoreactivity is found in medium-sized multipolar neurons with highly ramified dendrites lying in the superficial part of the GCL as well as in deeper large fusiform multipolar cells (data not shown). One third of the SRIF-ir population shows CB staining, mainly corresponding to the deep CB-ir population. NPY is found in large fusiform multipolar neurons lying deep in the GCL, close to the subependymal layer. As shown in Fig 3F, SRIF-ir and NPY-ir populations strongly overlap : 89.5\% of SRIF-ir deep short-axon cells express NPY while $81.9 \%$ of NPY-ir cells also express somatostatin (Table 3). Interestingly most SRIF-ir fibers in the GCL are also NPY-ir [90\% colocalization in SRIF fibers, $84 \%$ in NPY fibers, $(n=195)$, Fig. 3F]. Tyrosine Hydroxylase immunoreactivity 
is found in rare large cells and does not label SRIF-ir neurons. Finally, cells immunoreactive for VIP or CCK were not detected in mouse GCL, ruling out any colocalization of somatostatin with these two markers.

\section{Connectivity of the SRIF-ir iEPL interneurons}

SRIF-ir elements were further analyzed at the ultrastructural level in the iEPL (Fig. 4). SRIF-ir profiles exhibit dendritic ultrastructural features including the presence of polymorph vesicles and mitochondria, especially near the synaptic sites. Gap junctions were never observed in SRIF-ir profiles. Most SRIF-ir elements make synaptic contacts with transversally- or longitudinally-cut large dendritic trunks whose radial orientation, size, regular outline, electron lucent appearance and presence of vesicles (alveolate and round synaptic) and multivesicular bodies meet the criteria for mitral/tufted (M/T) cell dendrites (Price and Powell, 1970). The frequent presence of presynaptic clusters of round vesicles in $\mathrm{M} / \mathrm{T}$ dendrites apposing prominent post-synaptic densities in SRIF-ir elements (see black arrows, Fig. 4, panels A, B, C, E, F) demonstrated that SRIF interneurons receive asymmetrical contacts from $\mathrm{M} / \mathrm{T}$ cell dendrites. Some asymmetrical contacts from $\mathrm{M} / \mathrm{T}$ dendrites onto SRIF-immunonegative elements were also observed (black arrow, Fig. 4D). In most cases, the M/T dendrites, presynaptic to SRIF-ir elements, were found in close proximity to large clusters of flattened vesicles in the SRIF-ir terminals, characteristic of GABAergic spines or buttons (Fig. 4, panels B, F). Symmetric synapses formed by SRIF-ir elements onto M/T dendrites were also occasionally identified on the basis of both pre- and post-synaptic membrane specializations in the presence of round or flattened vesicles on the presynaptic side (see open black arrows, Fig. 4, panels B, D). These symmetrical synapses onto $\mathrm{M} / \mathrm{T}$ cell dendrites were in general less readily recognized because DAB staining can interfere with the identification of synaptic vesicles. The occurrence of asymmetrical excitatory synapses onto a GABAergic spine that in turn synapse on mitral cells (as shown in Fig. 4 B) strongly suggests that SRIF-ir cells establish dendrodendritic reciprocal synapses onto $\mathrm{M} / \mathrm{T}$ cell dendrites.

In order to estimate the degree of occurrence of reciprocal synapses on SRIF-ir dendrites, the relative distribution of VGAT-positive clusters (a marker for presynaptic GABAergic terminals) and PSD-95-positive clusters (a signature for mature glutamatergic postsynaptic 
elements) was quantified. Physical proximity between a GABAergic presynaptic site and a glutamatergic postsynaptic site suggests the existence of a reciprocal synapse (Panzanelli et al., 2004; Schneider-Gasser et al., 2006). As shown in Fig. 5, fluorescent clusters showing PSD-95 and VGAT immunolabeling are very abundant in the EPL (Fig. 5, panels A and C). PSD-95 clusters are approximately twice as abundant as VGAT clusters (see Table 4), but they are significantly smaller (VGAT: $1.11 \pm 0.03 \mu^{2}$, PSD-95: $0.39 \pm 0.01 \mu^{2}$, mean surface \pm SEM). Numerous VGAT and PSD-95 clusters clearly overlap (arrowheads in Fig. 5, enlarged in Fig. 5 panel C). While most VGAT-ir clusters are colocalized with PSD-95-ir clusters $(94.5 \pm 1.2 \%$, Table 4, Fig. 5, panels A and C), less than half of PSD-95 clusters colocalize with VGAT clusters (43.5 $\pm 0.9 \%)$. This colocalization involves $63 \%$ of the PSD-95-ir cluster surface compared to $26 \%$ of the VGAT cluster surface (Table 4).

Superimposition of SRIF-ir profiles with VGAT and PSD-95 double staining indicates that colocalized VGAT/PSD-95 clusters are observed within SRIF-ir dendritic processes (arrowheads, Fig. 5, panels B and D). Proportions of VGAT and PSD-95 colocalization remains the same in SRIF-ir dendrites as found in the whole optical section (Table 4, Chi-square test for VGAT and PSD-95 respectively, ns). Occasionally, SRIF-ir processes are observed at the border of a large immunonegative profile typical of a M/T cell dendrite (Fig. 5, panels A and B) and include some VGAT/PSD-95 colocalized clusters (open arrowheads, Fig. 5B). 


\section{Discussion}

The present results indicate that somatostatin expression delineates a sublayer in the EPL of the murine main olfactory bulb. Unlike in other species, nearly $95 \%$ of bulbar SRIFimmunoreactive neurons correspond to small interneurons restricted to the inner half of the EPL that arborize locally. Ultrastructural and confocal immunohistochemical data show that SRIF-ir interneurons directly interact with mitral cell dendrites, involving dendrodendritic reciprocal synapses. This provides an anatomical basis for a neuromodulatory role of the peptide on the granule-mitral cell dendritic interactions which are fundamental to olfactory processing.

\section{Somatostatin in deep short-axon cells: comparative analysis and functional implications}

Somatostatin had been described in the olfactory bulb of the hamster and the rat (Davis et al., 1982; Gutièrrez-Mecinas et al., 2005; Scott et al., 1987; Seroogy et al., 1989) mostly as SRIFpositive deep short-axon cells (dSACs) and fibers which are consistently found in the GCL (Scott et al., 1987; Seroogy et al., 1989). In rats, and to a lesser extent in men and frogs, SRIF-ir was also present in some periglomerular cells and superficial short-axon cells (Davis et al., 1982; Gutièrrez-Mecinas et al., 2005; Inagaki et al., 1981; Ohm et al., 1988; Scott et al., 1987) while those cells were not found in guinea pig and hamster (Davis et al., 1982; Matsutani et al., 1989).

We postulate here that the SRIF-ir cells of the mouse GCL also belong to the dSAC type on the basis of the morphological features previously defined using Golgi impregnation (Price and Powell, 1970; Ramon y Cajal, 1911; Schneider and Macrides, 1978): it should be noted though that early neuroanatomical descriptions lacked quantitative and morphometric data (Price and Powell, 1970; Ramon y Cajal, 1911; Schneider and Macrides, 1978) or primarily involved species other than the mouse (Larriva-Sahd, 2008; López-Mascaraque et al., 1990; Shipley and Ennis, 1996). Inframitral SRIF-ir cells are located in the deep GCL, close to the subependymal layer, usually oriented parallel to olfactory bulb layers. They display a large-sized and ovoid soma, from which emerge several dendrites, running at least $150 \mu \mathrm{m}$ from the soma, and extend very long processes which can be followed up to $400 \mu \mathrm{m}$. Nevertheless, we could not classify these SRIF-ir dSAC as either horizontal, vertical, Blanes or Golgi cell types - initially identified in the rodent $\mathrm{MOB}$ on the basis of the shape, location and size of the soma, orientation of the 
dendritic tree and presence or absence of dendritic spines (López-Mascaraque et al., 1986; Price and Powell, 1970; Schneider and Macrides, 1978; Shipley and Ennis, 1996) - since their morphological features did not exclusively or completely match any of these subgroups. Horizontal and vertical cells are projecting neurons, mainly localized in the superficial GCL and IPL. Their soma are fusiform and bipolar, with horizontal cells arborizing in parallel to GCL lamination while vertical cell dendrites arborize perpendicularly to GCL lamination (LópezMascaraque et al., 1986; Price and Powell, 1970; Schneider and Macrides, 1978). Their localization and shape clearly differ from GCL SRIF-ir cells. Golgi and Blanes cells, considered as locally projecting neurons, are more frequently found in the deep GCL, like SRIF-ir cells. Nevertheless, they usually display a random multipolar dendritic arborization, while SRIF-ir neurites arborize along the main orientation of the bulbar layers. Furthermore, whereas Blanes cells show numerous dendrites emerging from all sides of the soma, the latter arborize relatively close to the soma $(-100 \mu \mathrm{m})$ and frequently bear spines (Price and Powell, 1970; Schneider and Macrides, 1978). This is in contrast to the long and aspiny SRIF-ir dendrites we observed in the mouse GCL. Smaller dSAC subpopulations had also been described in other species, such as deep stellate cells in the monkey (Alonso JR et al., 1998), piriform and fusiform cells in the hedgehog (Briñón et al., 2001) and giant cells in the rat (Briñón et al., 1992); none of which share the morphological features of SRIF-ir GCL cells. Thus, SRIF-ir cells likely correspond to a distinct subtype of deep short-axon cell. Such a dSAC profile was reproducibly reported after SRIF immunodetection in rats (Gutièrrez-Mecinas et al., 2005; Scott et al., 1987; Seroogy et al., 1989), guinea pigs (Matsutani et al., 1989), hamsters (Davis et al., 1982) and humans (Ohm et al., 1988; Smith et al., 1993). Moreover, mouse SRIF-ir deep short-axon cells coexpress NPY as previously reported in rats (Gall et al., 1986; Scott et al., 1987; Seroogy et al., 1989). Taken together, these results suggest that SRIF expression in dSAC of the GCL is conserved across mammalian species. Since NPYergic and calbindin-positive phenotypes identify most somatostatinergic interneurons in the forebrain (for a review, see Viollet et al., 2008), bulbar GCL SRIF cells also share common features of all SRIF interneurons. The fact that SRIF-ir fibers observed in the GCL colocalize with NPY staining also strongly suggests that they may originate from GCL SRIF-ir dSAC neurons. However, many SRIF-ir fibers could not be traced to identified cells, and their cellular origin remains uncertain. Thus, GCL SRIF-ir fibers may also have an extrinsic origin since a subpopulation of raphe serotoninergic neurons projecting to the 
olfactory bulb and notably to the GCL also contains somatostatin, at least in the rat (Araneda et al., 1999).

Little is known about the role of GCL deep short-axon cells. Early electron microscopy studies showed that they innervate local interneurons, either granule cells or other dSACs (Gracia-Llanes et al., 2003; Price and Powell, 1970), suggesting that SRIF interneurons may also participate in selective GABAergic local circuits involved in the modulation of principal cells. The demonstration of the monosynaptic inhibition of granule cells by Blanes cells indeed stressed the point of the functional importance of SACs in the MOB circuitry for the global dishinhibition of the output neurons via feed-forward inhibition of granule cells (Pressler and Strowbridge, 2006). Two recent studies improved our knowledge concerning dSAC in the MOB (Eyre et al., 2008; Eyre et al., 2009). They showed that dSACs unexpectedly represent a large population of cells (a quarter of the mitral cell population), which innervate all layers of the MOB. They can be subdivided into several main categories according to the location of their soma in the GCL, axodendritic distribution, neurochemical repertoire and synaptic connectivity. As a common feature, all dSACs participate to the inhibition of GABAergic interneurons. But each dSAC subpopulation very selectively innervates a given type of intrinsic interneurons (i.e. periglomerular interneurons, granule cells) or even projects to higher olfactory area, involving novel intra- and extra-bulbar GABAergic projections (Eyre et al., 2008; Gracia-Llanes et al., 2003; Pressler and Strowbridge, 2006). As previously suggested by the heterogeneity of VIP-ir (Gracia-Llanes et al., 2003), NOS-ir (Kosaka and Kosaka, 2007b) and PV-ir (Kosaka and Kosaka, 2008) GCL interneurons in rat and mice, the neurochemical characterization of dSAC did not recapitulate a former morphological classification (Eyre et al., 2009). Neuropeptideexpressing subpopulations were found to be scarce: GCL SRIF-ir population was indeed estimated below 1\% of the total dSAC (Eyre et al., 2009) suggesting that these cells may not have been recorded in the initial study reporting the functional properties of the main dSACs subpopulations (Eyre et al., 2008). SRIF-ir dSAC subpopulation may then constitute a distinct dSAC subtypes with selective synaptic connectivity.

\section{Somatostatin-ir Van Gehuchten interneurons : comparative analysis and integration in the MOB circuitry}


In contrast to the GCL population, the concentration of SRIF interneurons in the iEPL had never been described to date in mammalian species and seems unique to the murine MOB. A few sparse SRIF-ir cells were reported in the EPL of guinea pigs (Matsutani et al., 1989). In rats, and to a lesser extent in humans, some SRIF-ir cells were found scattered in the GL (GutièrrezMecinas et al., 2005; Hwang et al., 2004; Kosaka and Kosaka, 2005). Such variability between the EPL and GL SRIF content across mammalian species clearly contrasts with the constancy of somatostatin detection in $\mathrm{dSAC}$ in the GCL, as discussed above. Cytological and morphological parameters of the mouse iEPL SRIF-ir cells show that they constitute an homogeneous interneuronal population, whose characteristics are reminiscent of Van Gehuchten interneurons (Ramon y Cajal, 1911; Schneider and Macrides, 1978), a subpopulation of axonless intrinsic neurons of the EPL initially described using Golgi impregnation in the cat (Van Gehuchten and Martin, 1891). Van Gehuchten interneurons are characterized by a medium-sized fusiform soma, from which emerge one or two thick and highly varicosed dendrites which arborize at the vicinity of the cell body (less than $100 \mu \mathrm{m}$ ) in a non-oriented way, forming a dense ovoid dendritic field (Briñón et al., 1992; Hamilton et al., 2005; Schneider and Macrides, 1978). They differ from other EPL interneurons, namely horizontal cells, satellite cells, superficial short-axon cells and multipolar cells. Horizontal and satellite cells have small round somata (8-10 $\mu \mathrm{m}$, mean diameter in mouse EPL) and display axon-like terminals (Kosaka et al., 1994; López-Mascaraque et al., 1990). Horizontal cells are bipolar interneurons with long smooth processes running tangentially to the MCL, whereas satellite cells display highly varicosed processes that precisely envelop the soma and segments of mitral cell dendrites. Superficial short-axon cells have a large soma (around $14 \mu \mathrm{m}$, mean diameter in mouse EPL, Kosaka et al., 2008; Kosaka and Kosaka, 2008), positioned mainly in the outer part of the EPL. They display a large dendritic field together with an axon-like process that spreads in the EPL (Kosaka et al., 1994; Kosaka and Kosaka, 2008). Finally, multipolar cells also have medium-size somata but these cells display a higher number of primary dendrites and a larger dendritic field $(>100 \mu \mathrm{m})$ than Van Gehuchten cells. In various species Van Gehuchten interneurons are scattered in the whole EPL (Briñón et al., 1998). Immunostaining for VIP neuropeptide (Crespo et al., 2002; Gall et al., 1986) or parvalbumin allowed descriptions of Van Gehuchten interneurons in rats (Briñón et al., 1998; Crespo et al., 2002; Kosaka et al., 1994; Toida et al., 1996), hedgehogs (Crespo et al., 2001) and mice (Kosaka and Kosaka, 2008; Parrish-Aungst et al., 2007). The present neurochemical analysis of Van 
Gehuchten cells in the iEPL confirms their GABAergic, VIPergic and PV-ir phenotype but also reveals an atypical colocalization of somatostatin with these classical markers. Indeed, in other telencephalic regions, somatostatin is usually coexpressed with NPY and calbindin, rarely with calretinin and parvalbumin, and never with VIP (for a review, see Viollet et al., 2008). Such a striking difference may be due to a different developmental origin: hippocampal and cortical SRIF interneurons both originate from the median ganglionic eminence (Danglot et al., 2006; Métin et al., 2006; Wonders and Anderson, 2006) whereas most bulbar interneurons originate from the lateral ganglionic eminence and the dorsal telencephalon (Bovetti et al., 2007; Kohwi et al., 2007; Ventura and Goldman, 2007; Young et al., 2007).

Regarding the putative functional role of Van Gehuchten cells in MOB circuitry, serial electron microscopy studies showed that VIP and/or parvalbumin processes directly innervate mitral/tufted cells (Crespo et al., 2001, 2002; Toida et al., 1996). This challenges the classical scheme according to which EPL interneurons only contact granule cells (Schneider and Macrides, 1978). In a combined physiological and biocytin-staining study, Hamilton et al. (2005) confirmed that murine Van Gehuchten neurons were axonless GABAergic cells. These cells exhibit high frequency spontaneous excitatory post-synaptic currents, suggesting inputs from mitral/tufted cells (Hamilton et al., 2005). Moreover, depolarizing currents applied to these cells evoke trains of action potentials (Hamilton et al., 2005). Recently, markers of the axon initial segment have been localized on the dendritic processes of parvalbumin Van Gehuchten cells, providing anatomical support for the occurrence of dendritic spike generation in these cells, despite their lack of an axon (Kosaka et al., 2008; Kosaka and Kosaka, 2008). These data, together with the connectivity of iEPL somatostatinergic terminals as reported here, strongly suggest that iEPL axonless somatostatin interneurons directly interact through dendrodendritic contacts with their synaptic partners: the mitral/tufted cells. We cannot categorically rule out that some ascending SRIF-ir axons might also contact mitral/tufted cells. However, the present results, in accordance with Eyre et al. (2008), indicate that ascending SRIF-ir axons are far less abundant than local SRIF-ir dendrites in the iEPL. Therefore anaxonic iEPL somatostatinergic cells likely represent the predominant source of SRIF-ir terminals on mitral/tufted cell dendrites. The present study then confirms that iEPL Van Gehuchten interneurons must be considered as first order neurons since they exert their inhibitory action directly on principal cells. Interestingly, in the other forebrain regions studied so far (hippocampus, neocortex, amygdala, neostriatum, basal forebrain, 
and retina), somatostatinergic interneurons systematically innervate their respective principal cells, targeting either their apical or basal dendritic compartments as shown in neocortex and hippocampus (reviewed in Viollet et al., 2008). This canonical synaptic organisation of somatostatin interneurons is thus conserved in the mouse main olfactory bulb, since somatostatinergic interneurons directly innervate the basal compartment of mitral/tufted cells. Moreover, the dendritic processes of somatostatin Van Gehuchten interneurons spread into a spatially limited domain in the EPL which fits with the diameter of the functional column previously described in viral tracing studies (Willhite et al., 2006). Somatostatin interneurons could then interact with mitral/tufted cells which are associated with a given glomerulus and thus contribute to the tuning of their activity.

The strict delineation of the inner lamina of the EPL by SRIF interneurons suggests a primary interaction with mitral cells. Indeed, principal cells and granule cells segregate within the EPL (Shepherd, 2004; Shipley and Ennis, 1996): mitral cell lateral dendrites preferentially develop in the deep lamina of the EPL where they contact dendrites from deep granule cells, whereas tufted cell lateral dendrites arborize in the outer part of the EPL (Mori, 1987; Mori et al., 1983; Orona et al., 1983) and contact superficial GC dendrites (Greer and Halász, 1987; Mori, 1987; Mori et al., 1983; Orona et al., 1983). The occurrence of distinct repertoires of GABA-A (Panzanelli et al., 2004) and AMPA (Montague and Greer, 1999) receptor subunits in the inner and the outer laminae of the EPL further suggests that mitral and tufted cells participate in distinct synaptic microcircuits through different signaling pathways. Functionally, tufted cells would be associated with low-threshold perception of odorants (Christie et al., 2001; Ezeh et al., 1993; Nagayama et al., 2004) whereas mitral cells, via lateral inhibition, would participate in odor discrimination (Lledo et al., 2005; Yokoi et al., 1995). According to their peculiar distribution in the bulbar network, somatostatin interneurons may preferentially interact with mitral-deep granule cell microcircuits and thus modulate olfactory discrimination processes.

\section{Somatostatin release and olfactory processing}

In contrast to other neurochemical markers in the MOB, somatostatin is expressed in a morphologically and spatially homogeneous subpopulation of interneurons. Our immunohistochemical and immunocytological evidences support the direct interaction of iEPL 
SRIF interneurons with the principal cells of the MOB through dendrodendritic reciprocal synapses. This suggests an important role for this peptide in modulating neural networks involved in sensory and learning processes. In most telencephalic regions neuropeptide-expressing interneuronal systems are crucial for maintaining brain functioning under normal and pathophysiological conditions (Baraban and Tallent, 2004). In particular, somatostatin systems are involved in learning and memory processes (Gastambide et al., 2009; Viollet et al., 2008) and may represent putative endogenous antiepileptic agents (Baraban and Tallent, 2004; Moneta et al., 2002). Many studies have revealed the neuronal tetrodotoxin-sensitive and Ca2+-dependent release of SRIF (Arancibia et al., 1984; Iversen et al., 1978; Vezzani and Hoyer, 1999) and have demonstrated the preferential release of the peptide under high neuronal activity, in particular high frequency bursting or even epileptic seizures (Bartfai et al., 1988; Christenson et al., 1991; Csaba et al., 2004; Vezzani et al., 1992).

In vitro, Van Gehuchten cells exhibit high frequency spontaneous and evoked excitatory currents $(40-100 \mathrm{~Hz})$ related to mitral/tufted cell inputs (Hamilton et al., 2005). High mitral/tufted cell activity observed during odorant stimulation may then trigger somatostatin release. In most telencephalic regions somatostatin immunoreactivity is found in dendrites (Epelbaum, 1986). Several studies have highlighted the fact that dendrites are a major source of peptide release in the brain (for a recent review, Ludwig and Leng, 2006). Here, we demonstrate that iEPL somatostatin dendrites mainly interact with $\mathrm{M} / \mathrm{T}$ cell dendrites. The occurrence of calciuminduced GABA release from somatostatinergic Van Gehuchten dendrites may create an even more favorable context for peptide release. Like other neuropeptides, somatostatin is likely to act via volume transmission (diffusion in a three-dimensional fashion within the extracellular space) and may exert global inhibitory effects on the synaptic network, even on distant synapses. Through the activation of hyperpolarizing currents or inhibition of calcium channels, somatostatin mainly acts on glutamatergic sites, either presynaptic or postsynaptic (Csaba and Dournaud, 2001; Csaba et al., 2004; Viollet et al., 2008). Such effects are related to the subtype and cellular localization of the somatostatin receptors involved. Using autoradiographical techniques sst2, sst3 and sst4 binding sites were detected in the EPL as well as sst2 and sst4 binding sites in the GCL (Videau et al., 2003). Interestingly the bulk of somatostatin immunoreactivity and binding sites is found in the EPL. This layer consists of a dense neuropilic network of granule and mitral cell dendrites interacting through reciprocal dendrodendritic 
synapses. Earlier ultrastructural studies reported that nearly all synapses upon M/T cell dendrites were found to be reciprocal (Price and Powell, 1970), as visualized here by the abundance of colocalized VGAT/PSD-95 immunopositive clusters. Since somatostatin can inhibit both presynaptic and postsynaptic sites, it may then directly modulate mitral cell-granule cell synaptic interactions, and consequently alter the resulting oscillatory dynamics (Lagier et al., 2004). The EPL is also innervated by feedback centrifugal fibers, including cholinergic, serotoninergic or noradrenergic inputs (Shepherd, 2004; Shipley and Ennis, 1996) and somatostatin is known to influence monoaminergic release in many brain regions (Beal and Martin, 1984; Garcia-Sevilla et al., 1978; Göthert, 1980; Hathway et al., 1998; Tanaka and Tsujimoto, 1981; Vécsei et al., 1990). Since peptides can act on synapses distant from their release sites, a putative action of somatostatin on such neuromodulatory elements cannot be ruled out.

\section{Conclusion}

In summary, the present study identifies a novel and species-selective SRIF interneuronal population in the iEPL of the mouse olfactory bulb, ideally inserted in the bulbar synaptic network to exert a functional modulatory role on olfactory signal processing. These iEPL somatostatin interneurons display selective neurochemical and anatomical properties which clearly differ from those previously reported for the main telencephalic somatostatin interneurons. These results substantiate the variability of the inhibitory interneuron repertoires between mouse and rat species, as recently reported for other markers (Kosaka and Kosaka, 2007a; Kosaka and Kosaka, 2007b). Finally iEPL somatostatinergic Van Gehuchten cells interact through dendrodendritic synaptic interactions with the principal cells of the MOB, suggesting a local peptide release driven by mitral-tufted cell activity. Further molecular and physiological studies are in progress to elucidate how somatostatin modulates olfactory synaptic networks and physiology. 


\section{Acknowledgments}

The authors wish to acknowledge A. Cougnon for taking care of the mice, Drs G. Tramu and P. Ciofi (Inserm UMR 862, Bordeaux) for providing SRIF, VIP and CCK antisera, Dr M. Darmon (Inserm UMR 894, Paris) for providing the anti-PSD-95 antiserum, Prof. K.G. Baimbridge (Univ. of British Columbia, Vancouver, Canada) for providing information concerning the specificity of the anti-parvalbumin antiserum, Dr. S. Yang (Inserm UMR 894, Paris) and M. Palloto (Department of Anatomy, Pharmacology, and Forensic Medicine, Univ. Torino, Italy) for technical help with the immunodetection of synaptic markers, the Inserm Fer à Moulin Institute imaging facility (Inserm UMR 839, Paris) for expert help with electron microscopy, Dr S. Peineau (Inserm UMR 676, Paris) and Dr N. Ramoz (Inserm UMR 894, Paris) for helpful discussions and Dr M. Grubb for careful reading of the manuscript. 


\section{References}

Alonso JR, Porteros A, Crespo C, Arévalo R, Briñón JG, Weruaga E, J. A. 1998. Chemical anatomy of the macaque monkey olfactory bulb: NADPH-diaphorase/nitric oxide synthase activity. J Comp Neurol 402:419-434.

Arancibia S, Epelbaum J, Boyer R, Assenmacher I. 1984. In vivo release of somatostatin from rat median eminence after local $\mathrm{K}+$ infusion or delivery of nociceptive stress. Neurosci Lett 50:97-102.

Araneda S, Gysling K, Calas A. 1999. Raphe serotonergic neurons projecting to the olfactory bulb contain galanin or somatostatin but not neurotensin. Brain Res Bull 49:209-214.

Ascoli GA, Alonso-Nanclares L, Anderson SA, Barrionuevo G, Benavides-Piccione R, Burkhalter A, Buzsáki G, Cauli B, Defelipe J, Fairén A, Feldmeyer D, Fishell G, Fregnac Y, Freund TF, Gardner D, Gardner EP, Goldberg JH, Helmstaedter M, Hestrin S, Karube F, Kisvárday ZF, Lambolez B, Lewis DA, Marin O, Markram H, Muñoz A, Packer A, Petersen CC, Rockland KS, Rossier J, Rudy B, Somogyi P, Staiger JF, Tamas G, Thomson AM, Toledo-Rodriguez M, Wang Y, West DC, Yuste R. 2008. Petilla terminology: nomenclature of features of GABAergic interneurons of the cerebral cortex. Nat Rev Neurosci 9:557-568.

Baker H, Morel K, Stone DM, Maruniak JA. 1993. Adult naris closure profoundly reduces tyrosine hydroxylase expression in mouse olfactory bulb. Brain Res 614:109-116.

Baraban SC, Tallent MK. 2004. Interneuron Diversity series: Interneuronal neuropeptides-endogenous regulators of neuronal excitability. Trends Neurosci 27:135-142.

Bartfai T, Iverfeldt K, Fisone G, Serfözö P. 1988. Regulation of the release of coexisting neurotransmitters. Annu Rev Pharmacol Toxicol 28:285-310.

Batista-Brito R, Close J, Machold R, Fishell G. 2008. The distinct temporal origins of olfactory bulb interneuron subtypes. J Neurosci 28:3966-3975.

Beal MF, Martin JB. 1984. The effect of somatostatin on striatal catecholamines. Neurosci Lett $44: 271-276$.

Belenky MA, Yarom Y, Pickard GE. 2008. Heterogeneous expression of gammaaminobutyric acid and gamma-aminobutyric acid-associated receptors and transporters in the rat suprachiasmatic nucleus. J Comp Neurol 506:708-732. 
Bovetti S, Peretto P, Fasolo A, De Marchis S. 2007. Spatio-temporal specification of olfactory bulb interneurons. J Mol Histol 38:563-569.

Briñón JG, Alonso JR, Arévalo R, García-Ojeda E, Lara J, Aijón J. 1992. Calbindin D-28kpositive neurons in the rat olfactory bulb. An immunohistochemical study. Cell Tissue Res 269:289-297.

Briñón JG, Arévalo R, Crespo C, Bravo IG, Okazaki K, Hidaka H, Aijón J, Alonso JR. 1998. Neurocalcin immunoreactivity in the rat main olfactory bulb. Brain Res 795:204-214.

Briñón JG, Weruaga E, Crespo C, Porteros A, Arévalo R, Aijón J, Alonso JR. 2001. Calretinin-, neurocalcin-, and parvalbumin-immunoreactive elements in the olfactory bulb of the hedgehog (Erinaceus europaeus). J Comp Neurol 429:554-570.

Celio MR, Baier W, Schärer L, Gregersen HJ, de Viragh PA, Norman AW. 1990. Monoclonal antibodies directed against the calcium binding protein Calbindin D-28k. Cell Calcium 11:599-602.

Christenson J, Alford S, Grillner S, Hökfelt T. 1991. Co-localized GABA and somatostatin use different ionic mechanisms to hyperpolarize target neurons in the lamprey spinal cord. Neurosci Lett 134:93-97.

Christie JM, Schoppa NE, Westbrook GL. 2001. Tufted cell dendrodendritic inhibition in the olfactory bulb is dependent on NMDA receptor activity. J Neurophysiol 85:169-173.

Ciofi P, Fallon JH, Croix D, Polak JM, Tramu G. 1991. Expression of neuropeptide Y precursorimmunoreactivity in the hypothalamic dopaminergic tubero-infundibular system during lactation in rodents. Endocrinology 128:823-834.

Ciofi P, Leroy D, Tramu G. 2006. Sexual dimorphism in the organization of the rat hypothalamic infundibular area. Neuroscience 141:1731-1745.

Ciofi P, Tramu G. 1990. Distribution of cholecystokinin-like-immunoreactive neurons in the guinea pig forebrain. J Comp Neurol 300:82-112.

Cox D, Racca C, Lebeau F. 2008. $\beta$-adrenergic receptors are differentially expressed in distinct interneuron subtypes in the rat hippocampus. J Comp Neurol 509:551-565.

Crespo C, Blasco-Ibáñez JM, Marqués-Marí AI, Alonso JR, Briñón JG, Martínez-Guijarro FJ. 2002. Vasoactive intestinal polypeptide-containing elements in the olfactory bulb of the hedgehog (Erinaceus europaeus). J Chem Neuroanat 24:49-63.

Crespo C, Blasco-Ibáñez JM, Marqués-Marí AI, Martínez-Guijarro FJ. 2001. Parvalbumin- 
containing interneurons do not innervate granule cells in the olfactory bulb. Neuroreport $12: 2553-2556$.

Csaba Z, Dournaud P. 2001. Cellular biology of somatostatin receptors. Neuropeptides 35:1-23.

Csaba Z, Richichi C, Bernard V, Epelbaum J, Vezzani A, Dournaud P. 2004. Plasticity of somatostatin and somatostatin sst $2 \mathrm{~A}$ receptors in the rat dentate gyrus during kindling epileptogenesis. Eur J Neurosci 19:2531-2538.

Danglot L, Triller A, Marty S. 2006. The development of hippocampal interneurons in rodents. Hippocampus 16:1032-1060.

Davis BJ, Burd GD, Macrides F. 1982. Localization of methionine-enkephalin, substance P, and somatostatin immunoreactivities in the main olfactory bulb of the hamster. J Comp Neurol 204:377-383.

Epelbaum J. 1986. Somatostatin in the central nervous system: physiology and pathological modifications. Prog Neurobiol 27:63-100.

Eyre M, Antal M, Nusser Z. 2008. Distinct Deep Short-Axon Cell Subtypes of the Main Olfactory Bulb Provide Novel Intrabulbar and Extrabulbar GABAergic Connections. J Neurosci 28:8217-8229.

Eyre MD, Kerti K, Nusser Z. 2009. Molecular diversity of deep short-axon cells of the rat main olfactory bulb. Eur J Neurosci 29:1397-1407.

Ezeh PI, Wellis DP, Scott JW. 1993. Organization of inhibition in the rat olfactory bulb external plexiform layer. J Neurophysiol 70:263-274.

Gall C, Seroogy KB, Brecha N. 1986. Distribution of VIP- and NPY-like immunoreactivities in rat main olfactory bulb. Brain Res 374:389-394.

García-Sevilla JA, Ferrer-Alcón M, Martín M, Kieffer BL, Maldonado R. 2004. Neurofilament proteins and cAMP pathway in brains of mu-, delta- or kappa-opioid receptor gene knockout mice: effects of chronic morphine administration. Neuropharmacology 46:519-530.

Garcia-Sevilla JA, Magnusson T, Carlsson A. 1978. Effect of intracerebroventricularly administered somatostatin on brain monoamine turnover. Brain Res 155:159-164.

Gastambide F, Viollet C, Lepousez G, Epelbaum J, Guillou J. 2009. Hippocampal SSTR4 somatostatin receptors control the selection of memory strategies. Psychopharmacology (Berl) 202:153-163.

Göthert M. 1980. Somatostatin selectively inhibits noradrenaline release from hypothalamic 
neurones. Nature 288:86-88.

Gracia-Llanes FJ, Carlos Crespo JMB-I, Ana Isabel MarqueÂs-MarõÂ and Francisco Jose Martõnez-Guijarro, C., Blasco-Ibáñez JM, Marqués-Marí AI, Martínez-Guijarro FJ. 2003. VIP-containing deep short-axon cells of the olfactory bulb innervate interneurons different from granule cells. Eur J Neurosci 18:1751-1763.

Greer CA, Halász N. 1987. Plasticity of dendrodendritic microcircuits following mitral cell loss in the olfactory bulb of the murine mutant Purkinje cell degeneration. J Comp Neurol 256:284-298.

Gutièrrez-Mecinas M, Carlos Crespo JMB-I, Ana Isabel MarqueÂs-Marõ Â and Francisco Jose Martõnez-Guijarro, C., Blasco-Ibáñez JM, Gracia-Llanes FJ, Marqués-Marí AI, MartínezGuijarro FJ. 2005. Characterization of somatostatin- and cholecystokinin-immunoreactive periglomerular cells in the rat olfactory bulb. J Comp Neurol 489:467-479.

Hamilton KA, Heinbockel T, Ennis M, Szabó G, Erdélyi F, Hayar A. 2005. Properties of external plexiform layer interneurons in mouse olfactory bulb slices. Neuroscience 133:819-829.

Hathway GJ, Emson PC, Humphrey PP, Kendrick KM. 1998. Somatostatin potently stimulates in vivo striatal dopamine and gamma-aminobutyric acid release by a glutamate-dependent action. J Neurochem 70:1740-1749.

Hwang IK, Lee JC, Park SK, An SJ, Lee HY, Lee YB, Sohn HS, Lee IS, Kang TC, Won MH. 2004. Age-related change of somatostatin-immunoreactive neurones in the main olfactory bulb of the rat. Anatomia, histologia, embryologia 33:59-63.

Inagaki S, Shiosaka S, Takatsuki K, Sakanaka M, Takagi H, Senba E, Matsuzaki T, Tohyama M. 1981. Distribution of somatostatin in the frog brain, Rana catesbiana, in relation to location of catecholamine-containing neuron system. J Comp Neurol 202:89-101.

Iversen LL, Iversen SD, Bloom F, Douglas C, Brown M, Vale W. 1978. Calcium-dependent release of somatostatin and neurotensin from rat brain in vitro. Nature 273:161-163.

Klausberger T, Magill PJ, Márton LF, Roberts JD, Cobden PM, Buzsáki G, Somogyi P. 2003. Brain-state- and cell-type-specific firing of hippocampal interneurons in vivo. Nature 421:844-848.

Kohwi M, Petryniak MA, Long JE, Ekker M, Obata K, Yanagawa Y, Rubenstein JL, AlvarezBuylla A. 2007. A subpopulation of olfactory bulb GABAergic interneurons is derived from Emx1 - and Dlx5/6-expressing progenitors. J Neurosci 27:6878-6891. 
Kornau HC, Schenker LT, Kennedy MB, Seeburg PH. 1995. Domain interaction between NMDA receptor subunits and the postsynaptic density protein PSD-95. Science 269:1737-1740.

Kosaka K, Heizmann CW, Kosaka T. 1994. Calcium-binding protein parvalbuminimmunoreactive neurons in the rat olfactory bulb. 1. Distribution and structural features in adult rat. Exp Brain Res 99:191-204.

Kosaka K, Kosaka T. 2005. Synaptic organization of the glomerulus in the main olfactory bulb: compartments of the glomerulus and heterogeneity of the periglomerular cells. Anatomical science international / Japanese Association of Anatomists 80:80-90.

Kosaka K, Kosaka T. 2007a. Chemical properties of type 1 and type 2 periglomerular cells in the mouse olfactory bulb are different from those in the rat olfactory bulb. Brain Res 1167:42-55.

Kosaka T, Deans MR, Paul DL, Kosaka K. 2005. Neuronal gap junctions in the mouse main olfactory bulb: morphological analyses on transgenic mice. Neuroscience 134:757-769.

Kosaka T, Komada M, Kosaka K. 2008. Sodium channel cluster, betaIV-spectrin and ankyrinG positive "hot spots" on dendritic segments of parvalbumin-containing neurons and some other neurons in the mouse and rat main olfactory bulbs. Neurosci Res 62:176-186.

Kosaka T, Kosaka K. 2007b. Heterogeneity of nitric oxide synthase-containing neurons in the mouse main olfactory bulb. Neurosci Res 57(2):165-178.

Kosaka T, Kosaka K. 2008. Heterogeneity of parvalbumin-containing neurons in the mouse main olfactory bulb, with special reference to short-axon cells and betaIV-spectrin positive dendritic segments. Neurosci Res 60:56-72.

Lagier S, Carleton A, Lledo PM. 2004. Interplay between local GABAergic interneurons and relay neurons generates gamma oscillations in the rat olfactory bulb. J Neurosci 24:43824392.

Larriva-Sahd J. 2008. The accessory olfactory bulb in the adult rat: a cytological study of its cell types, neuropil, neuronal modules, and interactions with the main olfactory system. $\mathrm{J}$ Comp Neurol 510:309-350.

Lledo PM, Gheusi G, Vincent JD. 2005. Information processing in the mammalian olfactory system. Physiol Rev 85:281-317.

López-Mascaraque L, De Carlos JA, Valverde F. 1986. Structure of the olfactory bulb of the 
hedgehog (Erinaceus europaeus): description of cell types in the granular layer. J Comp Neurol 253:135-152.

López-Mascaraque L, De Carlos JA, Valverde F. 1990. Structure of the olfactory bulb of the hedgehog (Erinaceus europaeus): a Golgi study of the intrinsic organization of the superficial layers. J Comp Neurol 301:243-261.

Ludwig M, Leng G. 2006. Dendritic peptide release and peptide-dependent behaviours. Nat Rev Neurosci 7:126-136.

Markram H, Toledo-Rodriguez M, Wang Y, Gupta A, Silberberg G, Wu C. 2004. Interneurons of the neocortical inhibitory system. Nat Rev Neurosci 5:793-807.

Matsutani S, Senba E, Tohyama M. 1989. Distribution of neuropeptidelike immunoreactivities in the guinea pig olfactory bulb. J Comp Neurol 280:577-586.

Maubert E, Tramu G, Croix D, Beauvillain JC, Dupouy JP. 1990. Co-localization of vasoactive intestinal polypeptide and neuropeptide $\mathrm{Y}$ immunoreactivities in the nerve fibers of the rat adrenal gland. Neurosci Lett 113:121-126.

Métin C, Baudoin JP, Rakić S, Parnavelas JG. 2006. Cell and molecular mechanisms involved in the migration of cortical interneurons. Eur J Neurosci 23:894-900.

Moneta D, Richichi C, Aliprandi M, Dournaud P, Dutar P, Billard JM, Carlo AS, Viollet C, Hannon JP, Fehlmann D, Nunn C, Hoyer D, Epelbaum J, Vezzani A. 2002. Somatostatin receptor subtypes 2 and 4 affect seizure susceptibility and hippocampal excitatory neurotransmission in mice. Eur J Neurosci 16:843-849.

Monnier Z, Bahjaoui-Bouhaddi M, Bride J, Bride M, Math F, Propper A. 1999. Structural and immunohistological modifications in olfactory bulb of the staggerer mutant mouse. Biol Cell 91:29-44.

Montague AA, Greer CA. 1999. Differential distribution of ionotropic glutamate receptor subunits in the rat olfactory bulb. J Comp Neurol 405:233-246.

Mori K. 1987. Membrane and synaptic properties of identified neurons in the olfactory bulb. Prog Neurobiol 29:275-320.

Mori K, Kishi K, Ojima H. 1983. Distribution of dendrites of mitral, displaced mitral, tufted, and granule cells in the rabbit olfactory bulb. J Comp Neurol 219:339-355.

Nagayama S, Takahashi YK, Yoshihara Y, Mori K. 2004. Mitral and tufted cells differ in the decoding manner of odor maps in the rat olfactory bulb. J Neurophysiol 91:2532-2540. 
Ohm TG, Braak E, Probst A. 1988. Somatostatin-14-like immunoreactive neurons and fibres in the human olfactory bulb. Anat Embryol 179:165-171.

Orona E, Scott JW, Rainer EC. 1983. Different granule cell populations innervate superficial and deep regions of the external plexiform layer in rat olfactory bulb. J Comp Neurol 217:227-237.

Panzanelli P, Fritschy JM, Yanagawa Y, Obata K, Sassoè-Pognetto M. 2007. GABAergic phenotype of periglomerular cells in the rodent olfactory bulb. J Comp Neurol 502:9901002.

Panzanelli P, Homanics GE, Ottersen OP, Fritschy JM, Sassoè-Pognetto M. 2004. Pre- and postsynaptic GABA receptors at reciprocal dendrodendritic synapses in the olfactory bulb. Eur J Neurosci 20:2945-2952.

Parrish-Aungst S, Shipley MT, Erdelyi F, Szabo G, Puche AC. 2007. Quantitative analysis of neuronal diversity in the mouse olfactory bulb. J Comp Neurol 501:825-836.

Pressler RT, Strowbridge BW. 2006. Blanes cells mediate persistent feedforward inhibition onto granule cells in the olfactory bulb. Neuron 49:889-904.

Price JL, Powell TPS. 1970. The Mitral and Short Axon Cells of the Olfactory Bulb. J Cell Sci $7: 631$.

Ramon y Cajal S. 1911. Histologie du système nerveux de l'homme et des vertébrés. Paris: Maloine.

Rasband MN, Park EW, Zhen D, Arbuckle MI, Poliak S, Peles E, Grant SG, Trimmer JS. 2002. Clustering of neuronal potassium channels is independent of their interaction with PSD95. J Cell Biol 159:663-672.

Saino-Saito S, Sasaki H, Volpe B, Kobayashi K, Berlin R, Baker H. 2004. Differentiation of the dopaminergic phenotype in the olfactory system of neonatal and adult mice. $\mathrm{J}$ Comp Neurol 479:389-398.

Schneider-Gasser EM, Straub CJ, Panzanelli P, Weinmann O, Sassoè-Pognetto M, Fritschy JM. 2006. Immunofluorescence in brain sections: simultaneous detection of presynaptic and postsynaptic proteins in identified neurons. Nat Protoc 1:1887-1897.

Schneider SP, Macrides F. 1978. Laminar distributions of interneurons in the main olfactory bulb of the adult hamster. Brain Res Bull 3:73-82.

Scott JW, McDonald JK, Pemberton JL. 1987. Short axon cells of the rat olfactory bulb display 
NADPH-diaphorase activity, neuropeptide Y-like immunoreactivity, and somatostatinlike immunoreactivity. J Comp Neurol 260:378-391.

Seroogy K, Hökfelt T, Buchan A, Brown JC, Terenius L, Norman AW, Goldstein M. 1989. Somatostatin-like immunoreactivity in rat main olfactory bulb: extent of coexistence with neuropeptide Y-, tyrosine hydroxylase- and vitamin D-dependent calcium binding protein-like immunoreactivities. Brain Res 496:389-396.

Shepherd GM. 2004. The Synaptic Organization of the Brain: Oxford University Press Inc, USA. $719 \mathrm{p}$.

Shipley MT, Ennis M. 1996. Functional organization of olfactory system. J Neurobiol 30:123176.

Smith RL, Baker H, Greer CA. 1993. Immunohistochemical analyses of the human olfactory bulb. J Comp Neurol 333:519-530.

Takamori S, Riedel D, Jahn R. 2000. Immunoisolation of GABA-specific synaptic vesicles defines a functionally distinct subset of synaptic vesicles. J Neurosci 20:4904-4911.

Tanaka S, Tsujimoto A. 1981. Somatostatin facilitates the serotonin release from rat cerebral cortex, hippocampus and hypothalamus slices. Brain Res 208:219-222.

Toida K, Kosaka K, Heizmann CW, Kosaka T. 1996. Electron microscopic serialsectioning/reconstruction study of parvalbumin-containing neurons in the external plexiform layer of the rat olfactory bulb. Neuroscience 72:449-466.

Van Gehuchten A, Martin I. 1891. Mémoire sur le système nerveux. La Cellule. p 3-35.

Vécsei L, Widerlöv E, Alling C, Zsigó J, Pávó I, Penke B. 1990. Somatostatin28(15-28), but not somatostatin28(1-12), affects central monoaminergic neurotransmission in rats. Neuropeptides 16:181-186.

Ventura RE, Goldman JE. 2007. Dorsal radial glia generate olfactory bulb interneurons in the postnatal murine brain. J Neurosci 27:4297-4302.

Vezzani A, Hoyer D. 1999. Brain somatostatin: a candidate inhibitory role in seizures and epileptogenesis. Eur J Neurosci 11:3767-3776.

Vezzani A, Monno A, Rizzi M, Galli A, Barrios M, Samanin R. 1992. Somatostatin release is enhanced in the hippocampus of partially and fully kindled rats. Neuroscience 51:41-46.

Videau C, Hochgeschwender U, Kreienkamp HJ, Brennan MB, Viollet C, Richter D, Epelbaum J. 2003. Characterisation of [125I]-Tyr0DTrp8-somatostatin binding in sst1- to sst4- and 
SRIF-gene-invalidated mouse brain. Naunyn Schmiedebergs Arch Pharmacol 367:562571.

Viollet C, Lepousez G, Loudes C, Videau C, Simon A, Epelbaum J. 2008. Somatostatinergic systems in brain: Networks and functions. Mol Cell Endo 286:75-87.

Willhite DC, Nguyen KT, Masurkar AV, Greer CA, Shepherd GM, Chen WR. 2006. Viral tracing identifies distributed columnar organization in the olfactory bulb. Proc Natl Acad Sci USA 103:12592-12597.

Winsky L, Isaacs KR, Jacobowitz DM. 1996. Calretinin mRNA and immunoreactivity in the medullary reticular formation of the rat: colocalization with glutamate receptors. Brain Res 741:123-133.

Wonders CP, Anderson SA. 2006. The origin and specification of cortical interneurons. Nat Rev Neurosci 7:687-696.

Yokoi M, Mori K, Nakanishi S. 1995. Refinement of odor molecule tuning by dendrodendritic synaptic inhibition in the olfactory bulb. Proc Natl Acad Sci USA 92:3371-3375.

Young KM, Fogarty M, Kessaris N, Richardson WD. 2007. Subventricular zone stem cells are heterogeneous with respect to their embryonic origins and neurogenic fates in the adult olfactory bulb. J Neurosci 27:8286-8296.

Zeyda T, Diehl N, Paylor R, Brennan MB, Hochgeschwender U. 2001. Impairment in motor learning of somatostatin null mutant mice. Brain Res 906:107-114. 


\section{Figure legends:}

Figure 1 : Distribution of SRIF immunoreactivity in the murine main olfactory bulb.

A: Representative pictures of ABC-DAB-processed coronal section of mouse main olfactory bulb showing SRIF immunoreactivity in the different cell layers. Note the ribbon of stained cells whose somata and neurites are confined to the inner half of the EPL (iEPL). Counterstaining: cresyl violet. Arrowheads : SRIF-ir labeled cells in MCL and oEPL, open arrow: SRIF-ir labeled soma in GL. Scale bar: $100 \mu \mathrm{m}$.

B1, B2, B3 : Representative pictures of SRIF-ir cells in the mouse GCL. Scale bars: $25 \mu \mathrm{m}$.

C1, C2, C3 : Representative pictures of SRIF-ir cells in the mouse iEPL. MCL is visble at the lower part of each panel. Scale bars: $25 \mu \mathrm{m}$

Abbreviations: EPL, External Plexiform Layer; GCL, Granule Cell Layer; GL, Glomerular Layer; iEPL, inner part of the EPL; IPL, Internal Plexiform Layer; MCL, Mitral Cell Layer; oEPL, outer part of the EPL; ONL, Olfactory Nerve Layer.

Figure 2 : Morphological analysis of MOB SRIF neurons.

Composites from camera lucida drawings of SRIF-ir cells in the iEPL (top) and the GCL (bottom) of the MOB. Cells in the iEPL shown on the left of the dotted line have been drawn from coronal sections cut tangentially to the iEPL cells on the right of the dotted line from sections orthogonal to the iEPL. Note the highly varicosed processes of iEPL SRIF-ir cells. Scale bar : $50 \mu \mathrm{m}$. Insets : Sholl analysis of iEPL SRIF-ir cells (top right, $\mathrm{n}=53$ ) and GCL SRIF-ir cells (bottom right, $\mathrm{n}=30$ ).

Abbreviations : EPL, External Plexiform Layer; GCL, Granule Cell Layer; iEPL, inner part of the EPL; IPL, Internal Plexiform Layer; MCL, Mitral Cell Layer.

Figure 3 : Neurochemical signature of iEPL and GCL SRIF-ir interneurons.

A, B, C, D: Representative double-immunostaining pictures showing that all somatostatin-ir cells (green) of the iEPL coexpress the GABAergic marker glutamic acid decarboxylase 65/67 KDa 
(GAD 65/67, magenta in A) and the calcium binding protein calretinin (CR, magenta in B). About half of SRIF-ir interneurons coexpress the calcium binding protein parvalbumin (PV, magenta in C) while all of them coexpress vasoactive intestinal peptide (VIP, magenta in D) ( Colocalization of green and magenta is shown in white). For each marker, arrows indicate labeled SRIF-ir cells, arrowheads labeled SRIF-negative cells and double arrowheads unlabeled SRIF-ir cells. Scale bars: $25 \mu \mathrm{m}$.

E, F: Representative double-labeling pictures showing that in the deep GCL, somatostatin (green) colocalizes with the GABAergic marker GAD 65/67 (magenta in E) and Neuropeptide Y (NPY, magenta in F). The colocalization of green and magenta is shown in white. For each marker, arrows indicate labeled SRIF-ir cells, arrowheads labeled SRIF-negative cells. Scale bars : 25 $\mu \mathrm{m}$.

Displayed panels correspond to the superimposition of five $(A, E)$ or ten $(B, C, D, F)$ serial optical slices spaced by $200-400 \mathrm{~nm}$ stacked along the z-axis.

Abbreviations : CR, calretinin ; iEPL, inner part of the external plexiform layer ; oEPL outer part of the external plexiform layer; GAD 65/67, glutamic acid decarboxylase of 65/67 KDa ; GCL, granule cell layer; MCL, mitral cell layer; NPY, neuropeptide Y; PV, parvalbumin; SEL, subependymal layer; SRIF, somatostatin; VIP, vasoactive intestinal peptide.

\section{Figure 4: Connectivity of the SRIF-ir dendrites in the iEPL.}

Representative pictures of DAB-labeled SRIF-ir dendrites (asterisks) at the ultrastructural level. Arrows always indicate the postsynaptic side. Black arrows point to asymmetrical synapses (panels A, B, C, D, E, F). Open black arrows (B, D) point to symmetrical synapses. Black arrowheads indicate a multivesicular body in panel $\mathrm{E}$ and an alveolate vesicle in panel $\mathrm{F}$.

Abbreviations : M/T : mitral/tufted cell dendrite. Scale bars : $0.5 \mu \mathrm{m}$.

\section{Figure 5: Colocalization of GABAergic presynaptic and glutamatergic postsynaptic proteins in SRIF-ir dendrites in the iEPL.}

Panels A and C illustrate the clustered distributions of VGAT (vesicular GABA transporter, blue) a presynaptic marker for GABAergic synapses, and PSD-95 (postsynaptic density protein of 95 
$\mathrm{kDa}$, magenta) a postsynaptic marker for glutamatergic synapses. Note that most VGAT clusters are colocalized with PSD-95 clusters illustrating the physical proximity of GABAergic and glutamatergic synapses (insets, higher magnification of dotted rectangles). Superimposition of somatostatin labeling (green, panels B and D) demonstrates that cluster colocalization occurs within somatostatin-positive dendrites (see arrowheads and magnifications of dotted rectangles in insets). Panels $\mathrm{A}$ and $\mathrm{B}$ also show a large immuno-negative somatodendritic profile of a presumptive mitral/tufted cell $(\mathrm{M} / \mathrm{T})$ occasionally bordered by somatostatin-ir processes (open arrowhead) containing VGAT/PSD-95 clusters. Each panel depicts a single confocal section. Scale bars : $5 \mu \mathrm{m}$. Insets magnification: 3.6x. 
Supplemental Figure S1 : Comparison of SRIF immunoreactivity in the MOB from wildtype and SRIF knockout mice.

A, B, C, D : Representative pictures of ABC-DAB-processed sagittal sections of mouse main olfactory bulb showing the absence of labeling in SRIF-KO mice (B, D) as compared to wildtype mice (A, C) using the goat D-20 somatostatin antibody (see Table 1). Similar results were obtained using the IS-7/51 antiserum (data not shown).

A, B : cresyl violet counterstaining ; C,D, without counterstaining. Scale bars : $100 \mu \mathrm{m}$. 
Table 1 : List of antibodies used in this study

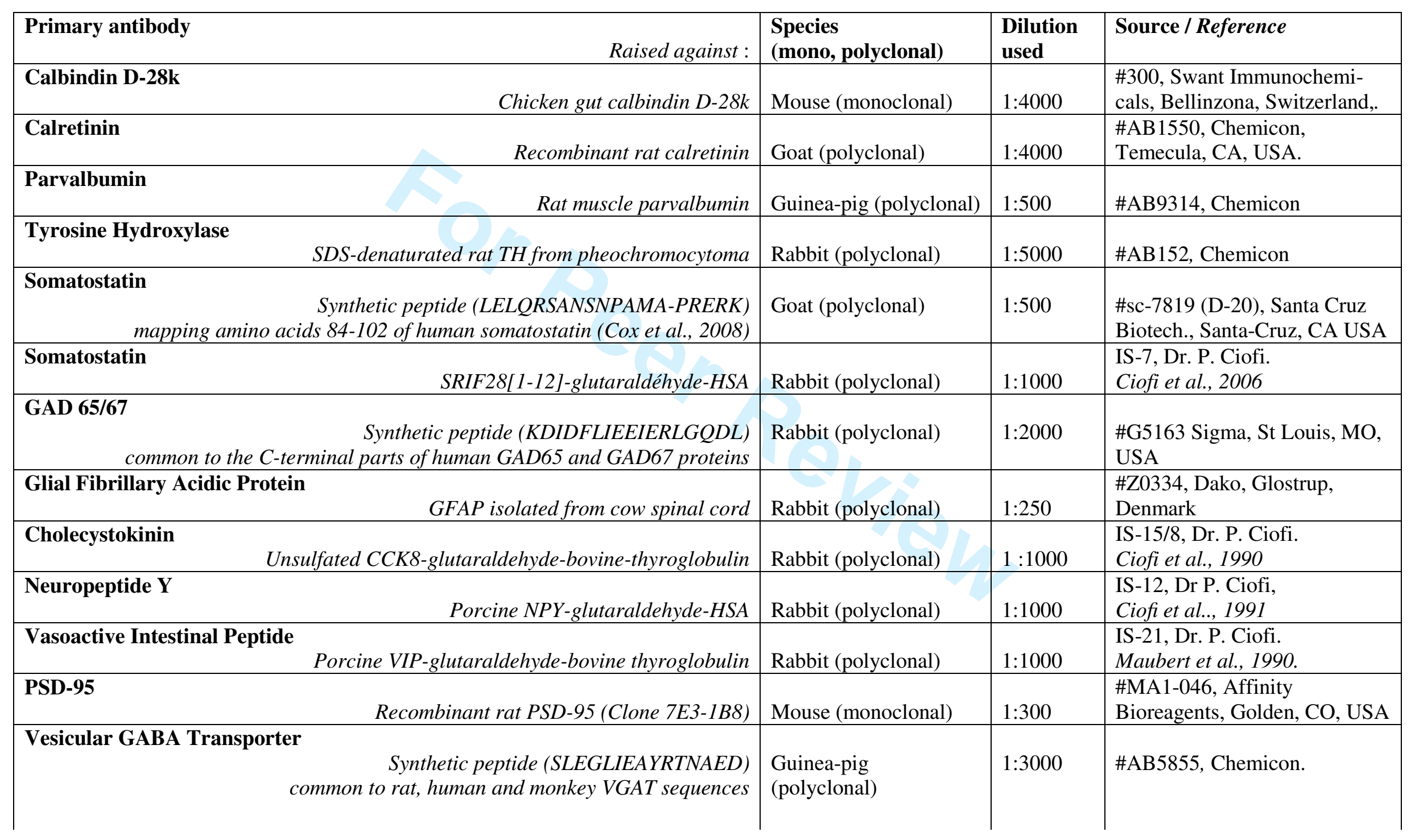




\begin{tabular}{|c|c|c|c|c|}
\hline Secondary Antibody & & & & \\
\hline \multicolumn{5}{|l|}{ Biotin-conjugated } \\
\hline & Anti-Goat IgG & Donkey & $1: 800$ & $\begin{array}{l}\text { Jackson Laboratories, West } \\
\text { Grove, PA, USA }\end{array}$ \\
\hline \multicolumn{5}{|l|}{ A488-conjugated } \\
\hline & $\begin{array}{r}\text { Anti-Goat IgG } \\
\text { Anti-Rabbit IgG }\end{array}$ & $\begin{array}{l}\text { Donkey } \\
\text { Donkey }\end{array}$ & $\begin{array}{l}1: 400 \\
1: 400\end{array}$ & $\begin{array}{l}\text { Molecular Probes, Eugene, } \\
\text { OR, USA } \\
\text { Molecular Probes }\end{array}$ \\
\hline \multicolumn{5}{|l|}{ CY3-conjugated } \\
\hline & $\begin{array}{r}\text { Anti-Mouse } \operatorname{Ig} G \\
\text { Anti-Guinea Pig } \operatorname{Ig} G \\
\text { Anti-Rabbit } \operatorname{Ig} G\end{array}$ & $\begin{array}{l}\text { Donkey } \\
\text { Donkey } \\
\text { Donkey }\end{array}$ & $\begin{array}{l}1: 400 \\
1: 400 \\
1: 800\end{array}$ & $\begin{array}{l}\text { Jackson Laboratories } \\
\text { Jackson Laboratories } \\
\text { Jackson Laboratories, }\end{array}$ \\
\hline \multicolumn{5}{|l|}{ CY5-conjugated } \\
\hline & Anti-Guinea-Pig IgG & Donkey & $1: 500$ & Jackson Laboratories \\
\hline
\end{tabular}

Abbreviations :Ig : immunoglobulin, IS : immunoserum, HSA : human serum albumin, PSD : post-synaptic density, 
Table 2. Morphological features of the SRIF-ir main populations in the MOB

\begin{tabular}{lcc}
\hline Morphological parameters & iEPL SRIF $^{+}$cells $(\mathrm{n}=53)$ & GCL SRIF $^{+}$cells $(\mathrm{n}=30)$ \\
\hline Soma area $\left(\mu \mathrm{m}^{2}\right)$ & $66.0 \pm 2.2$ & $139.9 \pm 7.3$ \\
Soma perimeter $(\mu \mathrm{m})$ & $30.4 \pm 0.5$ & $45.4 \pm 1.3$ \\
Soma area equivalent diameter $(\mu \mathrm{m})$ & $9.1 \pm 0.2$ & $13.2 \pm 0.4$ \\
Soma major diameter $(\mu \mathrm{m})$ & $10.7 \pm 0.2$ & $16.1 \pm 0.5$ \\
Soma minor diameter $(\mu \mathrm{m})$ & $9.1 \pm 1.3$ & $10.9 \pm 0.3$ \\
Primary dendrites number & $1.9 \pm 0.1$ & $3.4 \pm 0.2$ \\
Branching point number & $4.6 \pm 0.3$ & $4.1 \pm 0.4$ \\
Total dendritic length $(\mu \mathrm{m})$ & $254.8 \pm 11.0$ & $610.5 \pm 47.8$ \\
Furthest Sholl intercept $(\mu \mathrm{m})$ & $77.0 \pm 2.9$ & $209.3 \pm 16.1$ \\
\hline
\end{tabular}


Table 3. Chemical properties of iEPL and GCL somatostatin-ir cells

\begin{tabular}{|c|c|c|c|c|c|c|}
\hline \multirow[b]{2}{*}{$\begin{array}{r}\text { Interneuronal } \\
\text { Marker }\end{array}$} & \multicolumn{4}{|c|}{ Analyzed cells per animal } & \multicolumn{2}{|c|}{ Percent colocalization } \\
\hline & $\begin{array}{c}\text { Marker-ir } \\
\text { population }\end{array}$ & $\begin{array}{c}\text { SRIF-ir } \\
\text { population }\end{array}$ & SRIF/marker & SRIF alone & $\begin{array}{l}\text { in Marker } \\
\text { population }\end{array}$ & $\begin{array}{c}\text { in SRIF } \\
\text { population }\end{array}$ \\
\hline \multicolumn{7}{|c|}{ Inner External Plexiform Layer (iEPL) } \\
\hline$G A D$ 65/67* & $1007.5 \pm 50.6$ & $142.0 \pm 5.7$ & $141.3 \pm 6.1$ & $0.8 \pm 0.4$ & $13.9 \pm 0.8$ & $99.4 \pm 0.3$ \\
\hline Calretinin & $1155.5 \pm 102.5$ & $413.8 \pm 44.8$ & $413.4 \pm 44.6$ & $0.4 \pm 0.2$ & $35.7 \pm 0.7$ & $99.9 \pm 0.1$ \\
\hline Parvalbumin & $373.0 \pm 40.4$ & $428.2 \pm 39.8$ & $218.9 \pm 21.4$ & $209.3 \pm 18.8$ & $59.1 \pm 3.2$ & $51.1 \pm 0.7$ \\
\hline Calbindin & $52.6 \pm 8.6$ & $446.8 \pm 42.5$ & 0 & $446.8 \pm 42.5$ & $\mathbf{0}$ & $\mathbf{0}$ \\
\hline $\begin{array}{r}\text { Vasoactive Intestinal } \\
\text { Peptide }\end{array}$ & $866.3 \pm 70.7$ & $336.0 \pm 28.1$ & $324.8 \pm 26.6$ & $11.1 \pm 2.6$ & $37.5 \pm 0.1$ & $96.7 \pm 0.6$ \\
\hline Neuropeptide $Y$ & $0.4 \pm 0.2$ & $443.1 \pm 30.8$ & 0 & $443.1 \pm 30.8$ & $\mathbf{0}$ & $\mathbf{0}$ \\
\hline Cholecystokinin & $436.8 \pm 30.0$ & $400.2 \pm 31.8$ & 0 & $400.2 \pm 31.8$ & $\mathbf{0}$ & $\mathbf{0}$ \\
\hline $\begin{array}{r}\text { Tyrosine } \\
\text { Hydroxylase } \\
\end{array}$ & $30.4 \pm 5.8$ & $446.0 \pm 69.0$ & 0 & $446.0 \pm 69.0$ & $\mathbf{0}$ & $\mathbf{0}$ \\
\hline \multicolumn{7}{|c|}{ Granule Cell Layer (GCL) } \\
\hline$G A D 65 / 67 *$ & n.d. & $6.5 \pm 0.6$ & $6.5 \pm 0.6$ & 0 & $\varepsilon$ & 100 \\
\hline Calretinin & n.d. & $8.4 \pm 3.0$ & 0 & $8.4 \pm 3.0$ & $\mathbf{0}$ & $\mathbf{0}$ \\
\hline Parvalbumin & $41.4 \pm 8.4$ & $10.4 \pm 2.2$ & $0.2 \pm 0.2$ & $10.2 \pm 2.3$ & $0.3 \pm 0.3$ & $1.7 \pm 1.7$ \\
\hline Calbindin & $15.4 \pm 2.6$ & $14.8 \pm 0.3$ & $4.8 \pm 0.6$ & $9.9 \pm 0.6$ & $32.6 \pm 4.2$ & $32.7 \pm 4.1$ \\
\hline $\begin{array}{r}\text { Vasoactive Intestinal } \\
\text { Peptide }\end{array}$ & 0 & $14.8 \pm 1.6$ & 0 & $14.8 \pm 1.6$ & $\mathbf{0}$ & $\mathbf{0}$ \\
\hline Neuropeptide Y & $11.3 \pm 2.3$ & $10.5 \pm 2.5$ & $9.4 \pm 2.2$ & $1.1 \pm 0.3$ & $81.9 \pm 3.8$ & $89.5 \pm 0.7$ \\
\hline Cholecystokinin & 0 & $14.2 \pm 1$ & 0 & $14.2 \pm 1$ & $\mathbf{0}$ & $\mathbf{0}$ \\
\hline $\begin{array}{r}\text { Tyrosine } \\
\text { Hydroxylase } \\
\end{array}$ & $7.2 \pm 3.9$ & $10.3 \pm 0.7$ & 0 & $10.3 \pm 0.7$ & $\mathbf{0}$ & $\mathbf{0}$ \\
\hline
\end{tabular}

Data were averaged from three mice, with six consecutive $30 \mu \mathrm{m}$-thick coronal sections being analyzed per animal (inter-slice interval : $180 \mu \mathrm{m}$ ), except for GAD65/67 for which $16 \mu \mathrm{m}$-thick sections were used (*see Materials and Methods).

Values correspond to mean \pm SEM.

0 : absence of colocalization; $\varepsilon$ : negligible; n.d.: not determined. 
Table 4 : Extent of colocalization between VGAT-ir and PSD-95-ir clusters in the iEPL and SRIF-ir dendrites.

\begin{tabular}{|c|c|c|c|c|c|c|c|c|}
\hline & \multicolumn{5}{|c|}{$\begin{array}{l}\text { Total clusters } \\
(\mathrm{n}=50 \text { sections })\end{array}$} & \multicolumn{3}{|c|}{$\begin{array}{c}\text { SRIF-positive clusters } \\
\text { (5.7 } \pm 0.4 \% \text { of total section surface) }\end{array}$} \\
\hline VGAT & $692 \pm 32$ & $16.6 \pm 0.6$ & $1.1 \pm 0.03$ & $94.5 \pm 1.2$ & $25.7 \pm 1.0$ & $41 \pm 3$ & $90.2 \pm 1.2$ & $26.7 \pm 1.1$ \\
\hline PSD-95 & $1531 \pm 70$ & $37.1 \pm 1.1$ & $0.4 \pm 0.01$ & $43.5 \pm 0.9$ & $63.3 \pm 1.1$ & $77 \pm 5$ & $47.7 \pm 1.5$ & $60.4 \pm 1.6$ \\
\hline
\end{tabular}




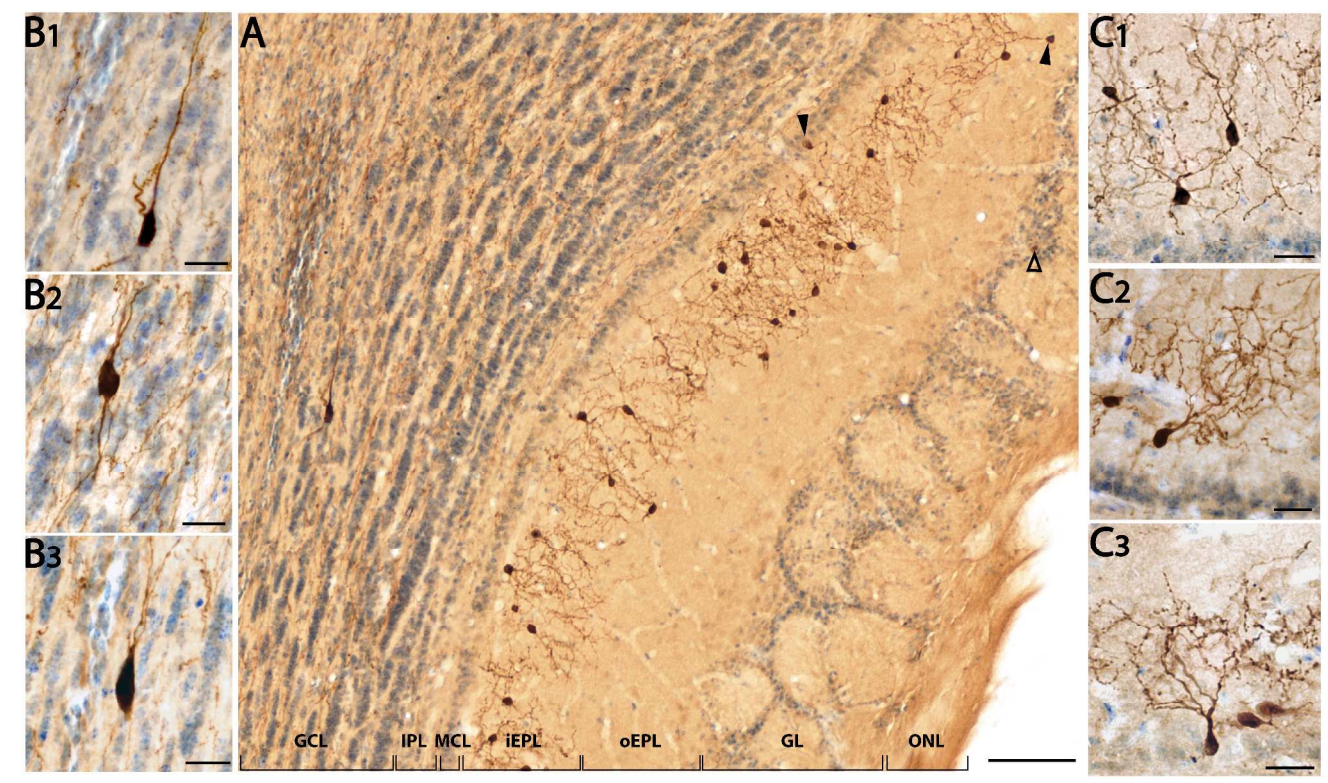

Figure 1 : Distribution of SRIF immunoreactivity in the murine main olfactory bulb.

A: Representative ABC-DAB-processed coronal section of mouse main olfactory bulb showing SRIF immunoreactivity in the different cell layers. Note the ribbon of stained cells whose somata and neurites are confined to the inner half of the EPL (iEPL). Counterstaining: cresyl violet. Arrowheads : SRIF-ir labeled cells in MCL and oEPL, open arrow: SRIF-ir labeled soma in GL. Scale bar: $100 \mu \mathrm{m}$.

B1, B2, B3 : Representative pictures of SRIF-ir cells in the mouse GCL. Scale bars: $25 \mu \mathrm{m}$.

C1, C2, C3 : Representative pictures of SRIF-ir cells in the mouse iEPL. MCL is visble at the lower part of each panel. Scale bars: $25 \mu \mathrm{m}$

Abbreviations : EPL, External Plexiform Layer; GCL, Granule Cell Layer; GL, Glomerular Layer; iEPL, inner part of the EPL; IPL, Internal Plexiform Layer; MCL, Mitral Cell Layer; oEPL, outer part of the EPL; ONL, Olfactory Nerve Layer.

$172 \times 101 \mathrm{~mm}(600 \times 600 \mathrm{DPI})$ 


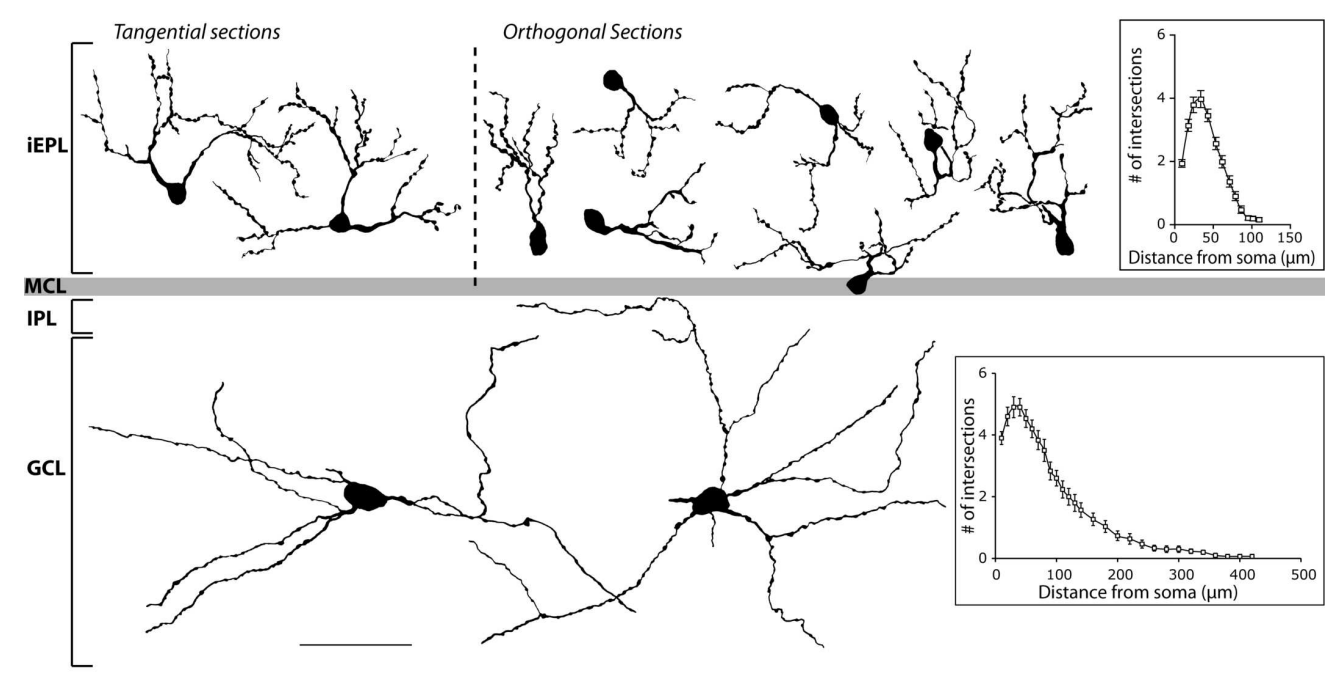

Figure 2 : Morphological analysis of MOB SRIF neurons.

Composites from camera lucida drawings of SRIF-ir cells in the iEPL (top) and the GCL (bottom) of the $O B$. Cells in the iEPL shown on the left of the dotted line have been drawn from coronal sections cut tangentially to the iEPL cells on the right of the dotted line from sections orthogonal to the iEPL. Note the highly varicosed processes. Scale bar : $50 \mu \mathrm{m}$. Insets : Sholl analysis of iEPL SRIF-ir cells (top right, $\mathrm{n}=53$ ) and GCL SRIF-ir cells (bottom right, $\mathrm{n}=30$ ).

Abbreviations : EPL, External Plexiform Layer; GCL, Granule Cell Layer; iEPL, inner part of the EPL; IPL, Internal Plexiform Layer; MCL, Mitral Cell Layer. $90 \times 48 \mathrm{~mm}(600 \times 600 \mathrm{DPI})$ 

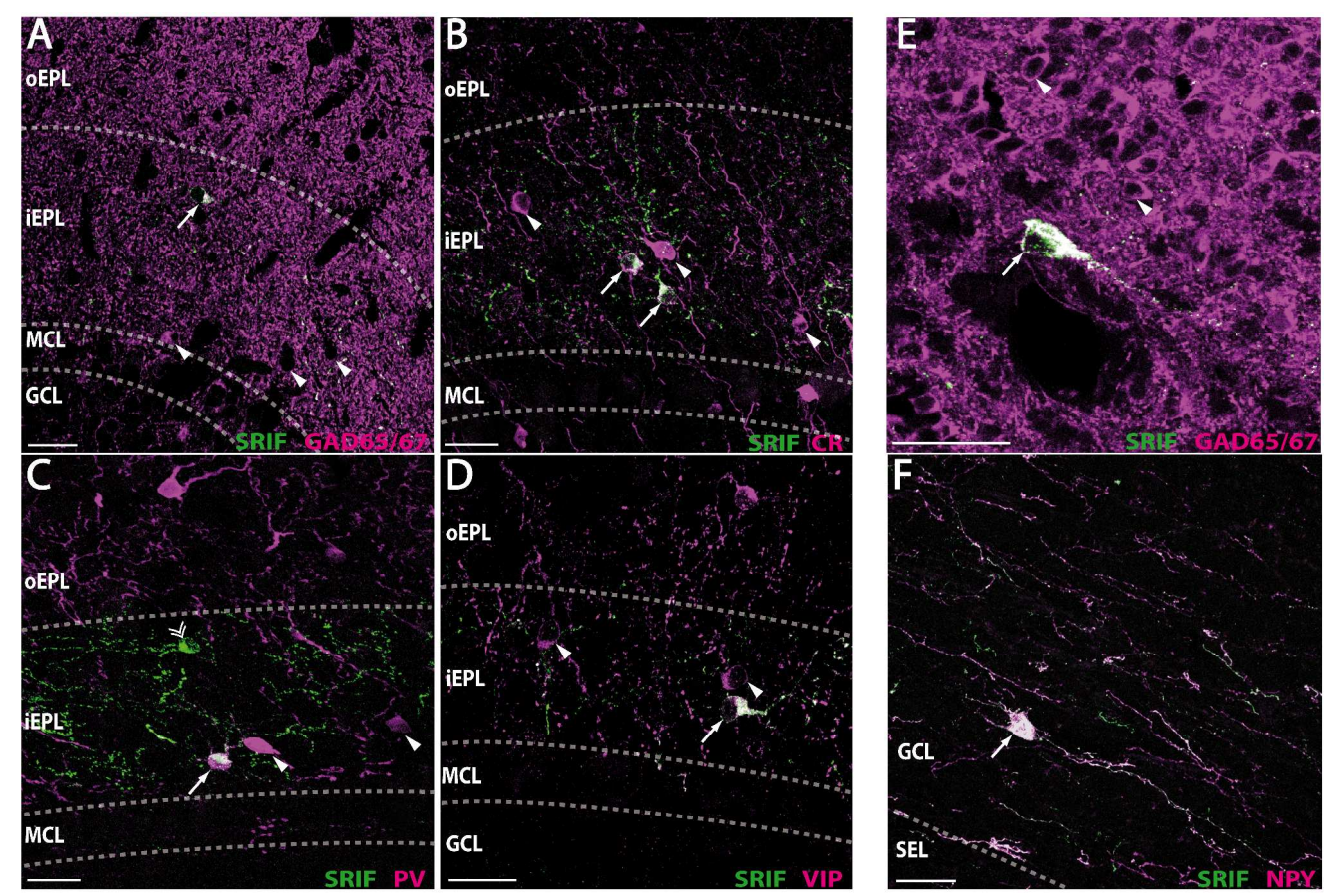

Figure 3 : Neurochemical signature of iEPL and GCL SRIF-ir interneurons.

A, B, C, D: Representative double-immunostaining pictures showing that all somatostatin-ir cells (green) of the iEPL coexpress the GABAergic marker glutamic acid decarboxylase 65/67 KDa (GAD $65 / 67$, magenta in $A$ ) and the calcium binding protein calretinin (CR, magenta in $B$ ). About half of SRIF-ir interneurons coexpress the calcium binding protein parvalbumin (PV, magenta in $C$ ) while all of them coexpress vasoactive intestinal peptide (VIP, magenta in D). The colocalization of green and magenta is shown in white. For each marker, arrows indicate labeled SRIF-ir cells, arrowheads labeled SRIF-negative cells and double arrowheads unlabeled SRIF-ir cells. Scale bars: $25 \mu \mathrm{m}$.

E, F: Representative double-labeling pictures showing that in the deep GCL, somatostatin (green) colocalizes with the GABAergic marker GAD 65/67 (magenta in E) and Neuropeptide Y (NPY, magenta in F). The colocalization of green and magenta is shown in white. For each marker, arrows indicate labeled SRIF-ir cells, arrowheads labeled SRIF-negative cells. Scale bars : $25 \mu \mathrm{m}$.

Displayed panels correspond to the superimposition of five $(A, E)$ or ten $(B, C, D, F)$ serial optical slices spaced by 200-400 $\mathrm{nm}$ stacked along the z-axis.

Abbreviations : $\mathrm{CR}$, calretinin ; iEPL, inner part of the external plexiform layer ; oEPL outer part of the external plexiform layer ; GAD 65/67, glutamic acid decarboxylase of 65/67 KDa ; GCL, granule cell layer ; MCL, mitral cell layer; NPY, neuropeptide $\mathrm{Y}$; PV, parvalbumin ; SEL, subependymal layer ; SRIF, somatostatin ; VIP, vasoactive intestinal peptide. $171 \times 116 \mathrm{~mm}(600 \times 600 \mathrm{DPI})$ 

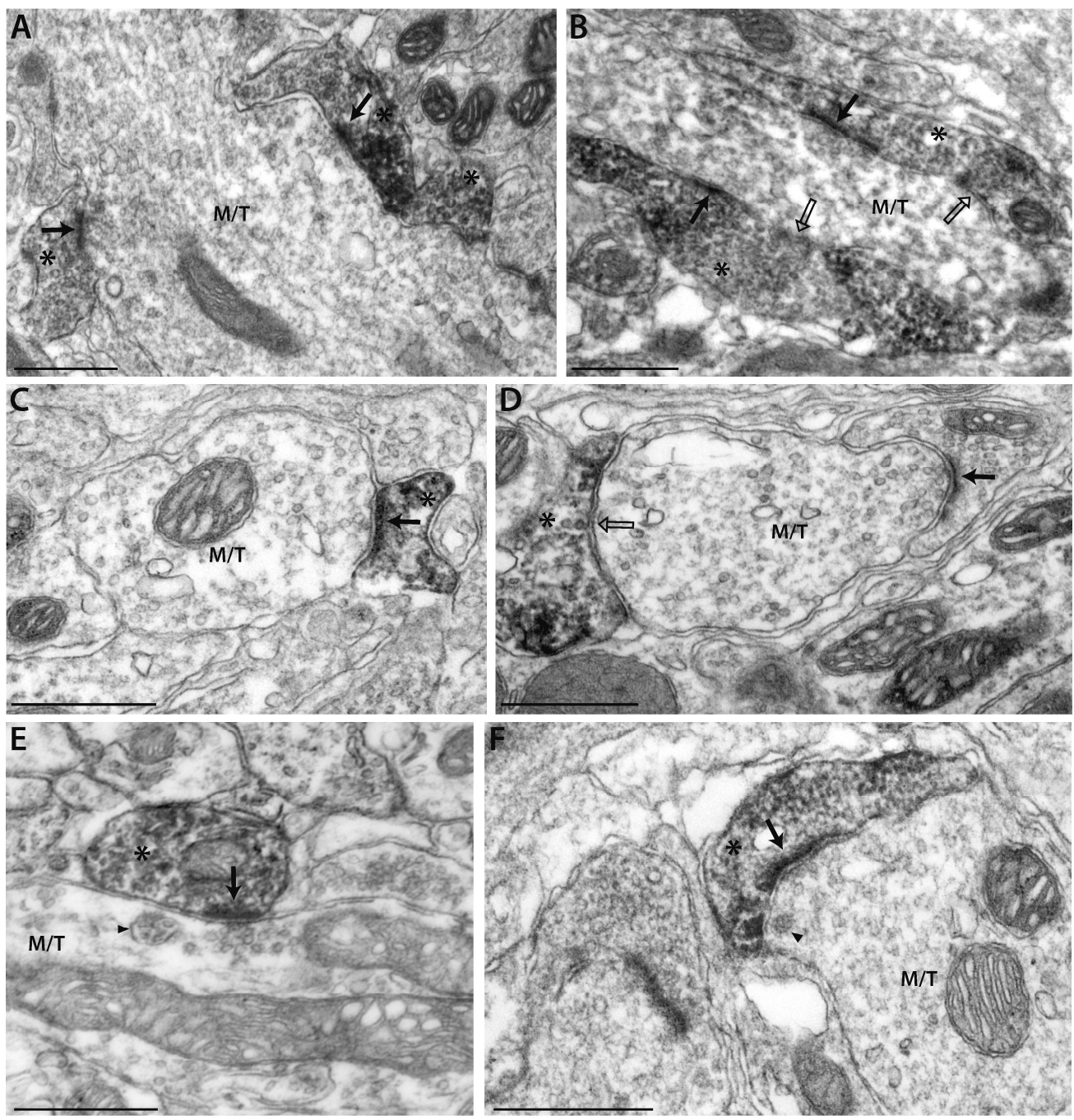

Figure 4: Connectivity of the SRIF-ir dendrites in the iEPL.

Representative pictures of DAB-labeled SRIF-ir dendrites (asterisks) at the ultrastructural level. Arrows always indicate the postsynaptic side. Black arrows point to asymmetrical synapses (panels

A, B, C, D, E, F). Open black arrows (B, D) point to symmetrical synapses. Black arrowheads indicate a multivesicular body in panel $E$ and an alveolate vesicle in panel $F$. Abbreviations : $\mathrm{M} / \mathrm{T}$ : mitral/tufted cell dendrite. Scale bars : $0.5 \mu \mathrm{m}$. $173 \times 180 \mathrm{~mm}(600 \times 600 \mathrm{DPI})$ 

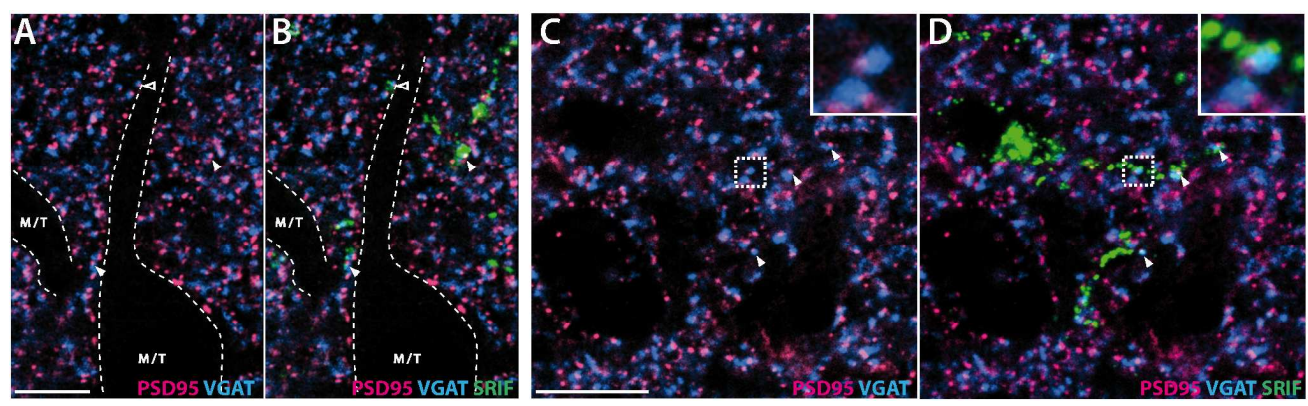

Figure 5: Colocalization of GABAergic presynaptic and glutamatergic postsynaptic proteins in SRIF-ir dendrites in the iEPL.

Panels A and C illustrate the clustered distributions of VGAT (vesicular GABA transporter, blue) a presynaptic marker for GABAergic synapses, and PSD-95 (postsynaptic density protein of $95 \mathrm{kDa}$, magenta) a postsynaptic marker for glutamatergic synapses. Note that most VGAT clusters are colocalized with PSD-95 clusters illustrating the physical proximity of GABAergic and glutamatergic synapses (insets, higher magnification of dotted rectangles). Superimposition of somatostatin labeling (green, panels B and D) demonstrates that cluster colocalization occurs within somatostatin-positive dendrites (see arrowheads and magnifications of dotted rectangles in insets). Panels $A$ and $B$ also show a large immuno-negative somatodendritic profile of a presumptive mitral/tufted cell (M/T) occasionally bordered by somatostatin-ir processes (open arrowhead) containing VGAT/PSD-95 clusters. Each panel depicts a single confocal section. Scale bars : $5 \mu \mathrm{m}$. Insets magnification: $3.6 x$.

$173 \times 52 \mathrm{~mm}(600 \times 600 \mathrm{DPI})$ 


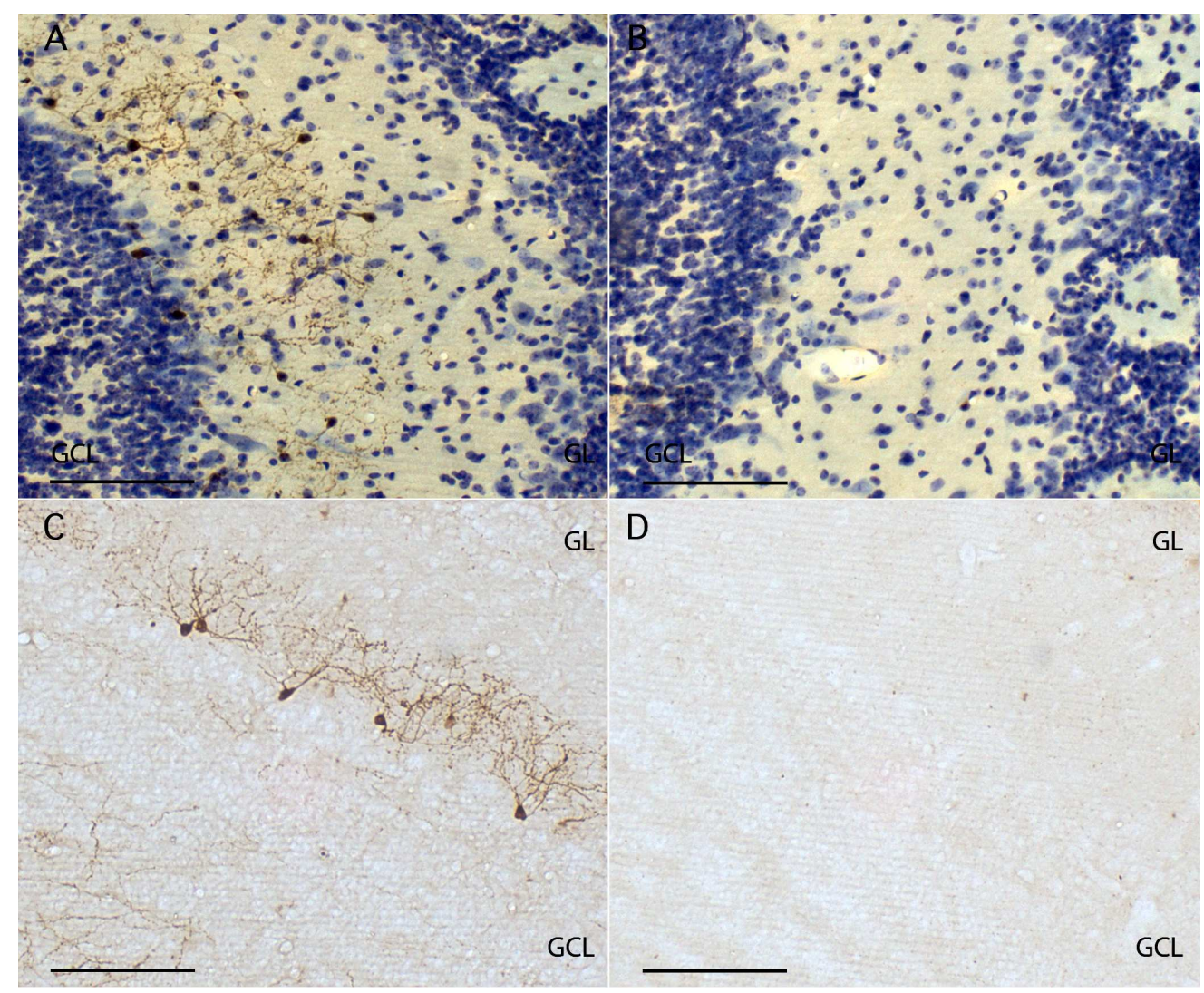

Comparison of SRIF immunoreactivity in the MOB from wild-type and SRIF knockout mice.

A, B, C, D : Representative pictures of ABC-DAB-processed sagittal sections of mouse main olfactory bulb showing the absence of labeling in SRIF-KO mice (B, D) as compared to wild-type mice $(A, C)$ using the goat D-20 somatostatin antibody (see Table 1 ). Similar results were obtained using the IS-7/51 antiserum (data not shown).

A, B : cresyl violet counterstaining ; C,D, without counterstaining. Scale bars : $100 \mu \mathrm{m}$.

$176 \times 145 \mathrm{~mm}(300 \times 300$ DPI) 